\title{
DSSAT modelling for best irrigation management practices assessment under Mediterranean conditions
}

\author{
Wafa Malik ${ }^{\mathrm{a}, *}$, Farida Dechmi ${ }^{\mathrm{a}, \mathrm{b}}$ \\ ${ }^{a}$ Agrifood Research and Technology Centre of Aragon (EEAD-CSIC Associated Unit), Soil and Irrigation Department, Avda. Montañana 930, 50059, Zaragoza, Spain \\ ${ }^{\mathrm{b}}$ Instituto Agroalimentario de Aragón-IA2 (CITA-Universidad de Zaragoza), Spain
}

\section{A R T I C L E I N F O}

\section{Keywords:}

CERES-Wheat-Barley

CERES-Maize

CROPGRO-Sunflower

CROPGRO-PFM-Alfalfa

Optimum irrigation

\begin{abstract}
A B S T R A C T
Water is considered the most critical resource for sustainable development in Spain. Crop models can enhance water efficiency, which provides an economic advantage while also reducing environmental burdens. The aim of this study was to calibrate and evaluate the Decision Support System for Agro-technology Transfer (DSSAT) model for the major crops grown in the fields of the La Violada Irrigation District (VID), Spain; additionally, this research sought to evaluate the current practices and to determine the best irrigation management practices under different soil types in the VID for each crop. Crop and soil type data from 54 plots of farmers' fields were used for model calibration and evaluation during the 2015 and 2016 irrigation seasons. Two irrigation scenarios were applied in eight soil types in the VID based on the current irrigation applied by farmers and the optimum irrigation adjusted to crop requirement. The DSSAT model demonstrated good performance among maize, wheat, barley and sunflower crops. The evaluation of the current irrigation system showed that farmers were not managing their irrigation systems properly. The adjusted irrigation management application showed a potential reduction in the seasonal irrigation depth for maize-SS (short-season maize) (27\%), maize-LS (long season maize) (18\%) and sunflower (16\%). In a broader context, optimum irrigation practices can reduce the amount of leached $\mathrm{N}$ and deep percolation losses by $31 \%(4.48 \mathrm{~T})$ and $34 \%\left(1.2 \mathrm{hm}^{3}\right)$, respectively, considering the cultivated crop area in each soil type in the entire VID.
\end{abstract}

\section{Introduction}

Worldwide, irrigated agriculture is a globally major water consumer that accounts for $70 \%$ of all water consumption (FAO, 2016) and represents a significant diffuse source of nutrient contamination (Ongley, 1996; Tanji and Kielen, 2002) and salinization (Isidoro et al., 2006). In Spain, the amount of irrigated area increased to 3.63 million hectares in 2015 (29.4\% of the total arable land) (MAAA, 2015). In semiarid irrigated areas, water is considered not only a limited resource but also a production factor and a relevant economic input. However, the high variability in irrigation performance that has been mentioned in several studies conducted in semiarid areas (Burt et al., 1997; Clemmens and Burt, 1997; Isidoro et al., 2004; Dechmi et al., 2003) indicates the need to establish an improved management program to enhance the performance and sustainability of irrigated agriculture. To this end, the Spanish irrigation modernization programs established for many irrigation districts starting in 2000 have resulted in a better use irrigation water and reduced environmental impacts. However, the results appear to indicate that the modernization of irrigation does not only fail to save irrigation water but, on occasions, results in a greater intensification of agricultural irrigated systems, producing an opposite effect than the desired outcome. In fact, some studies have indicated that there is a general tendency of increased water consumption in irrigated areas and decreased irrigation return flows after the modernization of the irrigation system (Jiménez-Aguirre and Isidoro, 2018; Lecina et al., 2010). Furthermore, despite the use of more efficient irrigation systems, such as sprinkler irrigation in Ebro Valley (Spain), Skhiri and Dechmi (2012) found that the average annual irrigation efficiency was low, indicating an excessive application of irrigation water.

For the sake of high crop yield in such intensive agricultural systems, most farmers apply high amounts of water and fertilizer based on their experience or intuition; however, these practices ignore the environmental consequences (McCown et al., 2012; Wei et al., 2009). Additionally, the characteristics of the irrigation system, crop needs, soil properties, and atmospheric conditions must all be considered to properly schedule irrigation practices. In fact, poor timing or insufficient water application can result in crop drought stress and

\footnotetext{
* Corresponding author.

E-mail address: wmalik@cita-aragon.es (W. Malik).
} 
reduced yields caused by the inappropriate application of available water and/or nutrients. On the other hand, excessive water applications may reduce yield and quality, represent water waste, and increase the risk of nutrient leaching (Maynard and Olson, 2001).

From this perspective, the verification of the optimal amount and time of water application requires long and expensive field experiments. In the field, however, it is impossible to test all potential situations that can be derived from the combination of time, frequency and seasonal amount of irrigation water (Rinaldia et al., 2003). Furthermore, a large number of experiments are often time and labor consuming, and the results are difficult to upscale spatially or temporally. It is also difficult to perform long-term evaluations of different management scenarios with complex weather interactions and a range of soil textures under field conditions (Gijsman et al., 2002). Nevertheless, irrigation management strategies can be improved by utilizing advances in modeling techniques to determine the optimal irrigation depth on scheduled irrigation days, which induces higher irrigation water efficiency and optimum crop yield (Abd El Baki et al., 2018; Hoogenboom et al., 2004; Xie et al., 2001). These models are powerful evaluation tools, and their water use outputs are commonly used in regional water planning and policy efforts. However, these models require adequate calibration and testing against measured field data to both validate model performance and reinforce user confidence in the model outputs (Chen et al., 2018).

The Decision Support System for Agro-technology Transfer (DSSAT) is the most widely used model package (Yakoub et al., 2017) to characterize the growth, development, yield, irrigation and $\mathrm{N}$ uptake of multiple crop species (Hoogenboom et al., 2017). The DSSAT model has been used extensively worldwide for crop simulation under different management practices and various climatic conditions (Rasse et al., 2000), irrigation management (Kadiyala et al., 2015; Rötter et al., 2012; López-Cedrón et al., 2008), and fertilizer N management (Li et al., 2015; Salmerón et al., 2014). Moreover, the DSSAT model has been applied for a diverse variety of crops, such as wheat and barley (Jahan et al., 2018), sunflower (Ashfaq et al., 2013), and maize (Hammad et al., 2017; Yakoub et al., 2017). The most recent version of the DSSAT can also be used for more herbage crops, such as alfalfa (Malik et al., 2018). However, most of the DSSAT model evolution efforts have been conducted under experimental fields and have not used real farm plots and management practices. For irrigation management assessments, the maximum soil allowable depletion (MAD) has been commonly used in semiarid/arid regions, such as the states of Texas, Kansas, and Arizona in the USA as well as in Iran (Callison, 2012; Gheysari et al., 2009; Lamm et al., 1996). For most crop production, a $50 \%$ MAD level represents a nominal and reasonable overall value for avoiding significant plant water stress (Callison, 2012).

The objectives of this research were to (1) calibrate and validate the main crops in the modernized irrigation district located in Ebro Valley, Spain (including barley, wheat, maize (both long and short season) and sunflower) after irrigation performance characterization at the farmfield scale and (2) determine the best management irrigation practices under different soil types and crop requirements. The output of this paper will be the basis for a companion paper that evaluates nitrogen practices in the Violada Irrigation District (VID) and assesses possible best management practices composed of different irrigation and nitrogen fertilizer applications under Mediterranean conditions.

\section{Materials and methods}

\subsection{Study area of the VID}

The Violada Irrigation District is located in the Ebro River basin (northeast Spain) between $41^{\circ} 59^{\prime} \mathrm{N}$ and $42^{\circ} 04^{\prime} \mathrm{N}$ and $0^{\circ} 32^{\prime} \mathrm{W}$ and $0^{\circ} 40^{\prime}$ $\mathrm{W}$, with elevations ranging from $345 \mathrm{~m}$ to $414 \mathrm{~m}$ above sea level. The total area of the VID is $\mathbf{5 2 3 1}$ ha. The VID belongs to the Alto Aragon Irrigation Scheme that was recently modernized (2008-2009) from traditional irrigation systems to pressured irrigation systems. In total, $92 \%$ of the study area is characterized by a remotely controlled sprinkler irrigation system (spacing of $18 \mathrm{~m} \times 18 \mathrm{~m}$ ), while only $8 \%$ is still under traditional surface irrigation. The advantage of the remotely controlled system is that the district manager records all data for each plot, which includes the date and the irrigation dose applied in each event. The primary crops in the VID include maize, alfalfa, cereal and sunflower. Two varieties of maize crops were considered in this study. The first variety is the long-season maize (hereafter defined as maizeLS), and the second variety is characterized by a short season that is always sown after a winter crop and is locally named double-crop maize (hereafter defined as maize-SS).

The climate is Mediterranean, with precipitation concentrated in spring and autumn. The mean annual precipitation and evapotranspiration (Penman-Monteith reference, $\mathrm{ET}_{0}$ ) values for the period of 2005-2017 recorded at the meteorological station of Tardienta, which is located in the study area, were $361 \mathrm{~mm}$ and $1272 \mathrm{~mm}$, respectively. The mean temperature for the period was $14^{\circ} \mathrm{C}$, with a mean monthly maximum temperature of $27^{\circ} \mathrm{C}$ and a mean monthly minimum temperature of $1.4^{\circ} \mathrm{C}$. The hottest month is July (mean temperature of $38^{\circ} \mathrm{C}$ ), and the coldest month is December (mean temperature of $\left.-5.6^{\circ} \mathrm{C}\right)$.

According to Jiménez-Aguirre et al. (2018), the soils in the VID were classified into 13 soil units according to the soil taxonomy classification and particle size families, as shown in Fig. 1. The more extended, representative soil units in the VID were Typic Xerofluvent fine-silty (E2; 955 ha, $18 \%$ of the total area) and Gypsic Haploxerept fine-silty (C2; 946 ha, 18\%), and these two types were very similar in their profile description and properties. C2 and E2 together covered 1901 ha (36\% of VID area) at the valley bottoms and represented the main share of the irrigated area. Jiménez-Aguirre et al. (2018) provided a more detailed description of the VID soils.

\subsection{Field database}

The field experiments were performed during the 2014-2015 and 2015-2016 crop seasons in farm fields in the VID; the fields included in the study were maize-LS, maize-SS, alfalfa, wheat, barley and sunflower. The field crops selection was conducted in a way that represented the dominant soil types in the study area for each crop and depended mainly on the crop distribution during the study years, as well as on the farmers' collaboration in agreeing to allow the research team to collect soil and crop growth and harvest measurements in their plots. As a result, 54 plots are considered in this study (and 5 additional plots for alfalfa were included from the 2016-2017 crop season). Meteorological data were obtained from the Tardienta weather station located in the VID (Fig. 2). A summary of the general crop management characteristics (i.e., sowing date and density, harvest date, crop yield and irrigation) for the selected plots used for the DSSAT model calibration and validation in the VID are presented in Table 1.

Soil characterization was determined for all the plots at four depths up to $1.20 \mathrm{~m}$ (when possible), and each 0.3-m layer was used to determine the soil texture, permanent wilting point (PWP) and field capacity (FC). The total available water (TAW; $\mathrm{mm}$ ) was calculated according to Walker and Skogerboe (1987) by the following equation:

$\mathrm{TAW}=10^{3} \mathrm{p}\left(\theta_{\mathrm{FC}}-\theta_{\mathrm{WP}}\right) \rho \mathrm{b} / \mathrm{\rho w}(1-\mathrm{S})$

where $\mathrm{p}$ is the soil depth (m); $\theta_{\mathrm{FC}}$ is the gravimetric water content ratio at $0.033 \mathrm{MPa}$ (i.e., field capacity); $\theta_{\mathrm{WP}}$ is the gravimetric water content ratio at $1.5 \mathrm{MPa}$ (i.e., wilting point); $\rho \mathrm{b}$ is the soil bulk density ( $\mathrm{Mg}$ $\left.\mathrm{m}^{-3}\right)$; $\rho \mathrm{b}$ is the water density $\left(\mathrm{Mg} \mathrm{m}^{-3}\right)$; and $\mathrm{S}$ is the volumetric ratio of stoniness.

In addition, the soil was sampled at the beginning and the end of each crop season to determine the soil nitrogen $\left(\mathrm{N}-\mathrm{NO}_{3}\right)$, organic matter and $\mathrm{pH}$. The soils that were alike (i.e., within the same series unit) in 


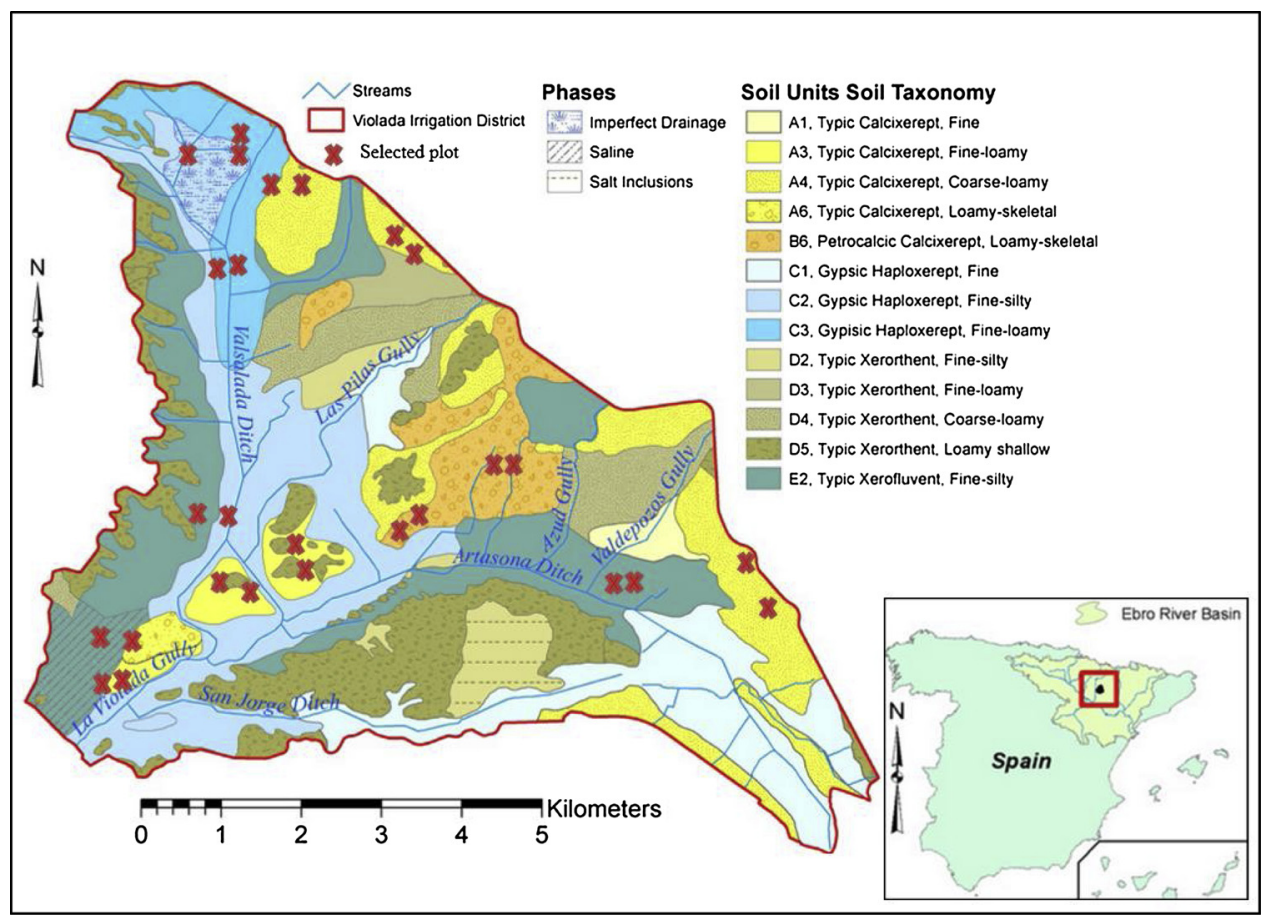

Fig. 1. La Violada Irrigation District situation, Soil distribution and drainage ditches in the irrigated area performed by Jiménez-Aguirre et al. (2018), and the selected plots localization considered in this study.

the VID were averaged for their soil characteristics, and the results are reported in Table 2.

The phenology data observation were recorded weekly during both the vegetative and the reproductive phases in both seasons to accurately determine the most important crop stages for model calibration and evaluation, such as anthesis (flowering) and physiological maturity. Many different scales exist for the determination of plant development stage. The decimal code, also known as the Zadoks scale, was used in this study to assess the wheat and barley development stages (Zadoks et al., 1974); meanwhile, the scale reported by Ritchie and Hanway (1982) was used for maize and the scale reported by Schneiter and Miller (1981) was used for sunflower. In addition, visual observations were recorded weekly regarding cases of herbicide damage, diseases, lack or excess water and temperature extremes. At harvest, yield sampling of $1 \mathrm{~m}^{2}$ with two repetitions was randomly conducted to determine the grain yield and vegetative biomass for each different crop. Then, a subsample of grain yield and vegetative biomass was weighed and dried at $60^{\circ} \mathrm{C}$ to determine the moisture content. Once dried, the subsample was ground and analyzed to determine the $\mathrm{N}$ uptake by combustion (TruSpec CN, LECO, St. Joseph, MI, USA) for both yield components.

\subsection{DSSAT model description, calibration and evaluation}

The DSSAT model (The Decision Support System for Agrotechnology Transfer) simulates crop growth, development and yield on a single land unit in response to weather and management as well as the changes in soil water, carbon and nitrogen that take place under cropping system over time (Jones et al., 2003). The DSSAT allows modelling over than 42 crops (as of the last Version 4.7). Each crop modules require daily weather data, initial soil conditions, detailed soil profile characteristics, detailed crop management and cultivar coefficients as input. The CENTURY model converted to daily step and linked to DSSAT models by Gijsman et al. (2002) was used as it is more flexible than the CERES Godwin module in handling different agricultural systems including decomposition of plant litter.

In this study, the CERES-Maize, CERES-Wheat-Barley, CROPGRO Sunflower and CROPCRO-PFM modules included in the DSSAT version 4.7 (Hoogenboom et al., 2017) were used to conduct simulations for maize (both hybrids), wheat-barley, sunflower and alfalfa, respectively. CERES-Maize cultivar calibration requires the estimation of six genetic coefficients (P2, P5, PHINT, G1, G2 and G3), while the CERES-WheatBarley calibration requires seven genetic coefficients (P1V, P1D, P5,

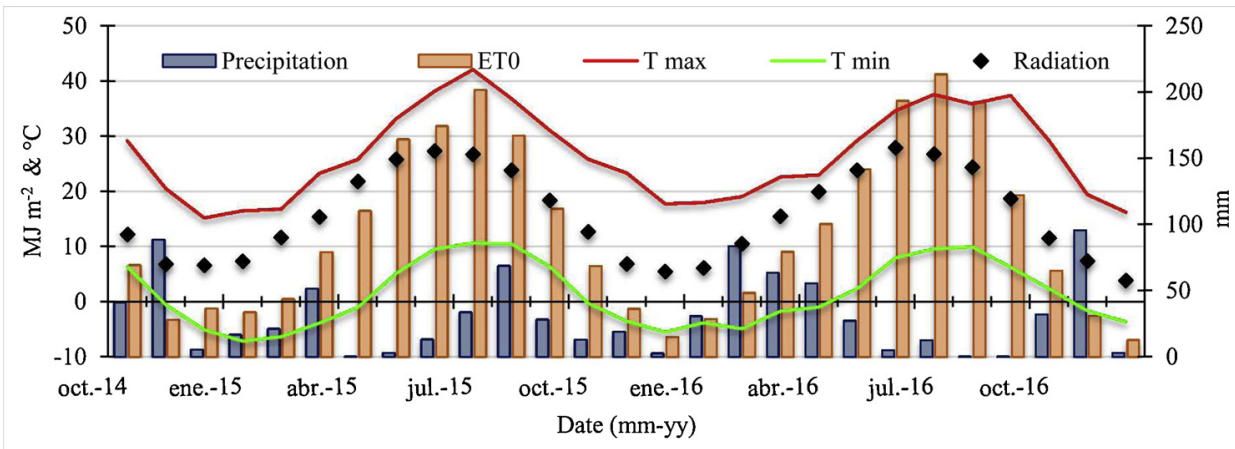

Fig. 2. Monthly average meteorological data recorded in Tardienta meteorological station during 2014-2015 and 2015-2016 hydrological years. 
Table 1

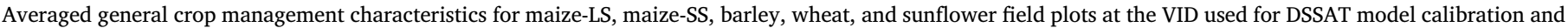
validation. Coefficient of variation (\%) of grain yield and irrigation depth average are included in parenthesis.

\begin{tabular}{|c|c|c|c|c|c|}
\hline Crop & Maize-LS (n = 14) & Maize-SS $(\mathrm{n}=8)$ & Barley $(n=14)$ & Wheat $(\mathrm{n}=6)$ & Sunflower $(n=10)$ \\
\hline Sowing date & 15-Apr & 17-Jun & 24-Nov & 29-Nov & 15-Jun \\
\hline Harvest date & 07-Oct & 16-Nov & 10-Jun & 21-Jun & 17-Oct \\
\hline Sowing density $\left(\mathrm{pl} \mathrm{m}^{-2}\right)$ & 9.0 & 8.8 & 632 & 561 & 8.7 \\
\hline Grain yield average ( $0 \%$ humidity) $\mathrm{Mg} \mathrm{ha}^{-1}$ & $12,934(12)$ & $13,621(13)$ & $6052(26)$ & $7917(20)$ & $3800(23)$ \\
\hline Irrigation depth (mm) & $671-925(778)$ & $563-820(705)$ & $20-253$ (99) & $84-1220$ (487) & $396-1040(629)$ \\
\hline Number of irrigation events & 119 & 112 & 13 & 24 & 79 \\
\hline
\end{tabular}

Table 2

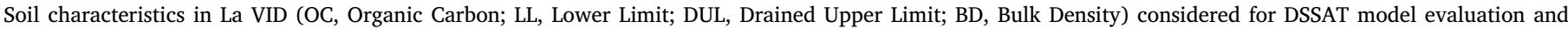
irrigation scenario assessment. Soil type total area is included in parenthesis. Texture based on the FAO classification system.

\begin{tabular}{|c|c|c|c|c|c|c|c|}
\hline $\begin{array}{l}\text { Depth } \\
\mathrm{cm}\end{array}$ & Clay & Silt & $\mathrm{OC}$ & $\underline{\mathrm{LL}}$ & DUL & $\begin{array}{l}\mathrm{BD} \\
\mathrm{g} \mathrm{cm}^{-3}\end{array}$ & $\begin{array}{l}\text { TAW } \\
\text { mm }\end{array}$ \\
\hline $\mathrm{n}=9$ & \multicolumn{7}{|c|}{ "Typic Calcixerept, Coarse-loamy (A4; 637.8 ha) } \\
\hline $0-30$ & 27 & 40 & 1.1 & 14.2 & 24.4 & 1.6 & 61 \\
\hline $30-60$ & 26 & 40 & 0.5 & 14.0 & 23.3 & 1.4 & 51 \\
\hline $60-90$ & 22 & 31 & 0.3 & 10.5 & 18.4 & 1.1 & 31 \\
\hline $90-120$ & 32 & 48 & 0.6 & 16.5 & 26.1 & 1.3 & 36 \\
\hline $\mathrm{n}=4$ & \multicolumn{7}{|c|}{ Petrocalcic Calcixerept, Loamy-skeletal (B6; 380.2; ha) } \\
\hline $0-30$ & 21 & 38 & 1.7 & 16.4 & 21.1 & 1.2 & 21 \\
\hline \multirow[t]{2}{*}{$30-60$} & 20 & 38 & 1.0 & 15.0 & 21.0 & 1.4 & 33 \\
\hline & \multicolumn{7}{|c|}{ Gypsic Haploxerept, Fine (C1; 585.5 ha) } \\
\hline $0-30$ & 41 & 54 & 0.2 & 16.9 & 28.1 & 1.5 & - \\
\hline $30-60$ & 42 & 53 & 0.2 & 16.4 & 27.4 & 1.6 & - \\
\hline $60-90$ & 38 & 48 & 0.2 & 14.3 & 23.9 & 1.5 & - \\
\hline $90-120$ & 36 & 49 & 0.1 & 15.1 & 24.9 & 1.4 & - \\
\hline $\mathrm{n}=4$ & \multicolumn{7}{|c|}{ "Gypsic Haploxerept, Fine-silty (C2; 936.3 ha) } \\
\hline $0-30$ & 34 & 41 & 0.8 & 15.6 & 26.2 & 1.6 & 74 \\
\hline $30-60$ & 28 & 42 & 0.5 & 15.6 & 25.0 & 1.5 & 63 \\
\hline $60-90$ & 24 & 34 & 0.0 & 14.7 & 25.6 & 1.5 & 72 \\
\hline $90-120$ & 27 & 44 & 0.0 & 15.7 & 25.5 & 1.5 & 61 \\
\hline $\mathrm{n}=3$ & \multicolumn{7}{|c|}{ "Gypsic Haploxerept, Fine-loamy (C3; 262.9 ha) } \\
\hline $0-30$ & 28 & 49 & 1.6 & 15.2 & 28.2 & 1.55 & 93 \\
\hline $30-60$ & 25 & 49 & 0.9 & 17.1 & 28.4 & 1.53 & 78 \\
\hline $60-90$ & 30 & 40 & 0.4 & 18.0 & 29.9 & 1.52 & 82 \\
\hline \multirow[t]{2}{*}{$90-120$} & 24 & 31 & 0.1 & 12.9 & 23.6 & 1.08 & 67 \\
\hline & \multicolumn{7}{|c|}{ Typic Xerorthent, Coarse-loamy (D4; 339.4 ha) } \\
\hline $0-30$ & 14 & 67 & 0.9 & 10.6 & 22.7 & 1.2 & - \\
\hline $30-60$ & 11 & 53 & 0.5 & 7.4 & 17.7 & 1.2 & - \\
\hline $60-90$ & 11 & 54 & 0.4 & 7.0 & 18.2 & 1.4 & - \\
\hline $90-120$ & 9 & 9 & 0.3 & 5.3 & 13.1 & 1.3 & - \\
\hline $\mathrm{n}=2$ & \multicolumn{7}{|c|}{ Typic Xerorthent, Loamy-shallow (D5; 698.0 ha) } \\
\hline $0-30$ & 25 & 49 & 2.1 & 14.9 & 32.4 & 1.2 & 68 \\
\hline $30-60$ & 22 & 41 & - & 14.7 & 24.6 & 1.4 & 67 \\
\hline $60-90$ & 29 & 49 & - & 14.4 & 23.8 & 1.4 & 55 \\
\hline $90-120$ & 22 & 42 & - & 9.0 & 20.7 & 1.4 & 70 \\
\hline $\mathrm{n}=5$ & \multicolumn{7}{|c|}{ "Typic Xerofluvent, Fine-silty (E2; 955.3 ha) } \\
\hline $0-30$ & 39 & 50 & 1.3 & 16.8 & 27.9 & 1.5 & 70 \\
\hline $30-60$ & 38 & 53 & 0.9 & 15.6 & 28.1 & 1.5 & 83 \\
\hline $60-90$ & 43 & 52 & 0.6 & 17.1 & 29.2 & 1.5 & 77 \\
\hline $90-120$ & 38 & 53 & 0.5 & 16.7 & 26.6 & 1.5 & 70 \\
\hline
\end{tabular}

* Measured field data used or DSSAT model evolution and irrigation scenarios assessment.

** Soil data used only for irrigation scenarios assessment.

PHINT, G1, G2, and G3). However, the genotype data file for the CROPGRO sunflower model contains 18 cultivar-specific parameters. These genetic coefficients for maize, barley, wheat and sunflower are defined in Table 3. The Penman-Monteith FAO 56 method was used in this study to calculate potential ET. Data from experimental plots of wheat $(n=2)$, barley $(n=7)$, maize-LS $(n=10)$, maize-SS $(n=4)$ and sunflower $(n=6)$ cultivated during the 2014-2015 cropping years were used for the calibration process. Meanwhile, independent plots of wheat $(n=4)$, barley $(n=7)$, maize-LS (4), maize-SS $(n=4)$ and sunflower $(n=4)$ data were used for model evaluation corresponding to the 2015-2016 crop season. In the case of alfalfa, Malik et al. (2018) has already adapted the DSSAT model for simulating alfalfa growth and yield using a dataset collected under the same conditions as those in the current study area.

For the remaining crops, the calibration was conducted using the 'trial and error' method, which is the most commonly used method in the case of the DSSAT model (Seidel et al., 2018); this method was used until an adequate match between the measured and simulated phenological stages (anthesis and physiological maturity) and the productivity crop (grain yield and vegetative biomass) data was found. In this context, the cultivar genetic coefficients were obtained sequentially, starting with the phenological development parameters related to the flowering and maturity dates followed by the crop growth parameters related to the kernel filling rate and kernel numbers per plant. Because the experimental plots were selected from the farm fields, different hybrids of the same crop (barley, wheat, maize-LS, maize-SS 
Table 3

Genetic coefficients definition and calibrated values for maize hybrids, wheat, barley and sunflower.

\begin{tabular}{|c|c|c|c|}
\hline \multirow[t]{2}{*}{ Coefficient } & \multirow{2}{*}{$\begin{array}{l}\text { Definition } \\
\text { Maize hybrids }\end{array}$} & \multicolumn{2}{|c|}{ Calibrated Value } \\
\hline & & Maize-LS & Maize-SS \\
\hline P1 & Thermal time from seedling emergence to the end of the Juvenile & 233 & 303 \\
\hline P2 & Delay in development with photoperiod above $12.5 \mathrm{~h}$ & 0.215 & 0.750 \\
\hline P5 & Thermal time from silking to physiological maturity & 760 & 860 \\
\hline G2 & Maximum possible number of kernels per plant & 750 & 999 \\
\hline G3 & potential kernel growth rate & 7.50 & 8.77 \\
\hline \multirow[t]{2}{*}{ PHINT } & Phyllochron interval & 50.9 & 56.9 \\
\hline & Wheat and Barley & Wheat & Barley \\
\hline PV1 & Delay in development for each day of unfulfilled vernalization & 8 & 50 \\
\hline P1D & Delay in development with photoperiod above $20 \mathrm{~h}$ & 81 & 70 \\
\hline P5 & Relative grain filling duration based on thermal time & 590 & 390 \\
\hline G1 & Kernel number per unit weight of stem at anthesis & 45 & 22 \\
\hline $\mathrm{G} 2$ & Kernel filling rate under optimum conditions $\left(\mathrm{mg} \mathrm{day}^{-1}\right)$ & 70 & 64 \\
\hline G3 & Non-stressed dry weight of a single stem and spike when elongation ceases & 5 & 8 \\
\hline \multirow[t]{2}{*}{ PHINT } & Phyllochron interval & 150 & 140 \\
\hline & Sunflower & \multicolumn{2}{|l|}{ Sunflower } \\
\hline CSDL & Critical long day length above which reproductive development progresses with no daylength effect & \multicolumn{2}{|l|}{15} \\
\hline PPSEN & Slope of the relative response of development to photoperiod with time & \multicolumn{2}{|l|}{0.086} \\
\hline EM-FL & Photothermal time between plant emergence and flower appearance & \multicolumn{2}{|l|}{30.6} \\
\hline FL-SH & Photothermal time between starburst and begin thalamus & \multicolumn{2}{|l|}{7.5} \\
\hline FL-SD & Photothermal time between starburst to anthesis/begin seed & \multicolumn{2}{|l|}{11.7} \\
\hline SD-PM & Photothermal time between anthesis/begin seed and physiological maturity & \multicolumn{2}{|l|}{22} \\
\hline FL-LF & Photothermal time between starburst and end of leaf expansion & \multicolumn{2}{|l|}{14} \\
\hline LFMAX & Maximum leaf photosynthesis rate & \multicolumn{2}{|l|}{1.4} \\
\hline SLAVR & Specific leaf area of cultivar under standard growth conditions $\left(\mathrm{cm}^{2} \mathrm{~g}^{-1}\right)$ & \multicolumn{2}{|l|}{135} \\
\hline SIZLF & Maximum size of full leaf $\left(\mathrm{cm}^{2}\right)$ & \multicolumn{2}{|l|}{180} \\
\hline XFRT & Maximum fraction of daily growth partitioned to thalamus, achen and seed & \multicolumn{2}{|l|}{0.89} \\
\hline WTPSD & Maximum weight per seed $(\mathrm{g})$ & \multicolumn{2}{|l|}{0.06} \\
\hline SFDUR & Seed filling duration for pod cohort at standard growth conditions & \multicolumn{2}{|l|}{28} \\
\hline SDPDV & Average seed per pod under standard growing conditions & \multicolumn{2}{|l|}{2.5} \\
\hline PODUR & Photothermal time to reach final pod load under optimal conditions & \multicolumn{2}{|l|}{4.5} \\
\hline THRSH & Threshing percentage & \multicolumn{2}{|l|}{65} \\
\hline SDPRO & Fraction protein in seeds ( $\mathrm{g}$ (protein) $/ \mathrm{g}($ seed $)$ ) & \multicolumn{2}{|l|}{0.14} \\
\hline SDLIP & Fraction oil in seeds (g(oil)/g(seed)) & \multicolumn{2}{|l|}{0.45} \\
\hline
\end{tabular}

and sunflower) were considered for each crop calibration process. Therefore, the best combination of genetic parameters for each crop corresponded to all considered hybrids in the study area and was used for validation and management scenarios simulation. The crop management practices used for model calibration and evaluation were determined through interviews with farmers, while the irrigation doses and timing were obtained from the Almudévar Water User Association for each corresponding plot using the remote database registration. For each crop, the calibrated model was further evaluated for growth (anthesis and physiological maturity) and yield (grain and vegetative biomass yields), $\mathrm{N}$ uptake (grain and vegetative biomass) and residual $\mathrm{N}$ in the soil.

To assess the performance of the model, the following parameters were considered.

Bias, defined as the difference between the simulated and observed values:

Bias $=1 / n \sum_{i=0}^{n}\left(y_{i}-x_{i}\right)$

where $\mathrm{n}$ is the number of observed values, and $y_{\mathrm{i}}$ and $x_{\mathrm{i}}$ are the simulated and observed values, respectively, for the $\mathrm{i}^{\text {th }}$ data pair.

The root mean square error (RMSE) between the simulated and observed values was computed as:

$R M S E=\sqrt{\sum \frac{\left(y_{i}-x_{i}\right)^{2}}{n}}$

The normalized RMSE (nRMSE) was expressed as the ratio between the RMSE and the average of the observed data. The model simulations were considered excellent, good, fair, and poor based on the nRMSE values of $<10 \%, 10-20 \%, 20-30 \%$, and $>30 \%$, respectively, which were proposed by (Kadiyala et al., 2015). $n R M S E=\frac{R M S E}{\bar{x}} X 100$

where $x$ is the observed average.

The index of agreement or d statistic (d; Willmott, 1982) was computed as follows:

$d=1-\sum\left(y_{i}-x_{i}\right)^{2} / \sum\left(\left|y_{i}-\bar{x}\right|+\left|x_{i}-\bar{y}_{i}\right|\right)^{2}$

The coefficient of determination $\left(\mathrm{R}^{2}\right)$ of the linear regression was calculated between the simulated y-observed values. The levels of statistical significance considered were as follows: "ns" to indicate not significant $(\mathrm{P}>0.05)$; “*” to indicate $0.05 \geq \mathrm{P}>0.01$; “**” to indicate $0.01 \geq \mathrm{P}>0.001$; and “***" to indicate $\mathrm{P} \leq 0.001$.

\subsection{Irrigation scenarios}

For the irrigation management evaluation of each representative crop in the VID, the corresponding calibrated model was applied to compare the current farmers' irrigation management methods (the real irrigation dates and depths applied by the farmers were obtained from the Almudévar Water User Association for each plot and crop season) and the optimal irrigation management scenarios. In the case of alfalfa, the field experiment performed in the VID during 2015 and 2016, as described by Malik et al. (2018), was used for scenario application.

The optimal irrigation scenario consisted of adjusting the irrigation doses and timing to match those of each crop requirement; this process was conducted using the automatic irrigation option included in the DSSAT model. The automatic irrigation was set using a constant MAD value of 0.5 . More specifically, if the MAD was $50 \%$, it means that supplemental irrigation is triggered to refill the reservoir up to soil field capacity when half of the available water in the root zone is depleted. 
For each crop, each scenario was simulated in the eight soils type of the VID (Table 2), which cover $90.3 \%$ of the study area (i.e., the E2, C2, D5, A4, C1, D4, B6 and C3 soils type). When the DSSAT model was run for both scenarios (current or automatic irrigation scenarios), farming practices such as tillage, sowing density and harvest as well as the applied $\mathrm{N}$ fertilization practices were used from farmer surveys that were collected in the VID during the study years (75 and 71 surveys for 2014-2015 and 2015-2016, respectively). Specifically, farmers were asked about the type of $\mathrm{N}$ fertilizers they applied (including manure), the amount applied per unit area, and the application dates. In addition, we also asked about crop yields, tillage operations, management of crop residues, sowing date, density and depth, row spacing and pest control. For both scenarios, an irrigation efficiency of $85 \%$ was used, which is in agreement with the reported value by Clemmens and Dedrick (1994) for solid-set sprinkler irrigation systems. Therefore, the results were compared in terms of the total amount of irrigation and the related environmental impacts (deep percolation losses, $\mathrm{N}$ leaching).

Since the real crop evapotranspiration (ETr) was note measured in each considered fields, the daily crop evapotranspiration ETc calculated by the DSSAT model after the calibration process using standard FAO procedures (Allen et al., 1998) was used to calculate the main crops requirements to determine the irrigation performance using the irrigation efficiency index (IE; \%). IE was defined as the ratio of net crop requirements (modelled crop evapotranspiration ETc minus effective precipitation) to seasonal irrigation depth applied (Burt et al., 1997). A theoretical IE of $100 \%$ indicates that the entire volume of applied irrigation was used to satisfy the crop water needs or that it has accumulated in the water reserves of the soil for use on crops in the following period. In addition, the water use efficiency (WUE), which is defined as the ratio between the crop yield and irrigation water applied during the crop season per hectare ( $\mathrm{kg} . \mathrm{mm}^{-1}$ ), was used to evaluate the considered irrigation management practices.

\section{Results and discussion}

\subsection{Observed data assessment and current practices characterization}

The analysis of the VID crop data indicates there was a similar cropping pattern during the consecutive crop seasons that were considered (2014-2015 and 2015-2016). The primary crops in the VID include maize (both long and short season) (36.6\%), alfalfa (25\%), cereal $(18 \%)$ and sunflower (9\%); numerical values represent the average value for the two years of the cropping season. These crops represented approximately $87 \%$ and $90 \%$ of the VID area during 2014-2015 and 2015-2016, respectively. The data also indicate that most of the sunflower area and part of the maize (15\% and $20 \%$ for 2015 and 2016, respectively) include a double-cropping pattern and are cultivated after wheat and barley. This tendency was observed more commonly after irrigation modernization in the 2008s. The maize-SS increased from $15 \%$ in 2015 to $20 \%$ in 2016 . Likewise, for sunflower crops, the corresponding cultivated area increased from $7 \%$ in 2015 to $11 \%$ in 2016. The crop distribution area (Fig. 3) within the different soils in the VID (average area in 2015 and 2016) indicates that the maize crop was mostly found in D4, D3 and A1 soils (comprising more than $43 \%$ of each soil cultivated area), while alfalfa was cultivated mainly in A6, D5, C2 and B6 (comprising more than $30 \%$ of the cultivated area in these soils). In the case of sunflower, the first harvested crop was mostly cultivated in D2 and C1 soils. The C3 and A4 soils were mostly cultivated by barley, while wheat was cultivated mainly in A3 and D2 soils. In terms of the second harvested crop (double crops), C3 and A4 were mainly cultivated by sunflower, with $51 \%$ and $68 \%$ of each soil, respectively, in the total double-crop area. For the remaining soils, maize-SS was the major crop, especially in the A3, A6 and B6 soils, and it represented more than $79 \%$ of each soil in the total doublecrop area.

On average, the mean dry matter grain yield for barley and wheat was $6052 \mathrm{~kg} \mathrm{ha}^{-1}$ and $7917 \mathrm{~kg} \mathrm{ha}^{-1}$, respectively. The variability of the observed yield was $26 \%$ and $20 \%$ for barley and wheat, respectively. During this period, the average maize-LS crop yield was $12,943 \mathrm{~kg} \mathrm{ha}^{-1}(\mathrm{CV}=12 \%)$, while for maize-SS, it was slightly higher, at $13,621 \mathrm{~kg} \mathrm{ha}^{-1}(\mathrm{CV}=13 \%)$. Regarding sunflower, the mean production of $3800 \mathrm{~kg} \mathrm{ha}^{-1}$ (CV $\left.=23 \%\right)$ was observed.

Considering the seasonal average irrigation doses for each crop (Table 1), maize-LS is the highest water consumer $(778 \mathrm{~mm}$ ), followed by maize-SS $(705 \mathrm{~mm})$. Nevertheless, there was no difference regarding the number of irrigation events, with 119 and 112 applications for maize-LS and maize-SS, respectively. For both types of maize, farmers tended to irrigate on a daily basis, with a mean irrigation dose of $7.4 \mathrm{~mm}$ and a high coefficient of variation (64\%). The irrigation doses ranged from $3.5 \mathrm{~mm}$ to $38.6 \mathrm{~mm}$ for maize-LS. Likewise, the maize-SS with interval irrigation doses received doses that varied between $3.4 \mathrm{~mm}$ and $34 \mathrm{~mm}$.

Sunflower was the second highest water consumer, with a total average irrigation of $629 \mathrm{~mm}$ and 79 applications before wheat (487 mm and 24 irrigation applications) and barley ( $99 \mathrm{~mm}$ and only 13 applications), respectively. In the case of sunflower, the irrigation doses ranged from $3.6 \mathrm{~mm}$ to $37 \mathrm{~mm}$ with an average of $7 \mathrm{~mm}$. The mean irrigation doses were $13.5 \mathrm{~mm}$ and $10 \mathrm{~mm}$ for wheat and barley, respectively. Meanwhile, these doses ranged from $1.2 \mathrm{~mm}$ to $44 \mathrm{~mm}$ and from $3 \mathrm{~mm}$ to $23 \mathrm{~mm}$ for wheat and barley, respectively.

In general, the farmers used fixed irrigation depths throughout the irrigation season. However, barley and wheat were irrigated only occasionally (the largest irrigation intervals) depending on visual field observations and weather conditions. Fig. 4 shows that the maize-LS, maize-SS, wheat, barley and sunflower crops were over-irrigated during the 2015 season, while irrigation during the 2016 season was deficient (case of barley) or more adjusted to crop requirements. This behavior may be due to the fact that 2015 was a warmer year than 2016. These data suggest that farmers tried to schedule their irrigation water operations based on only the climate conditions. Nevertheless, the timing

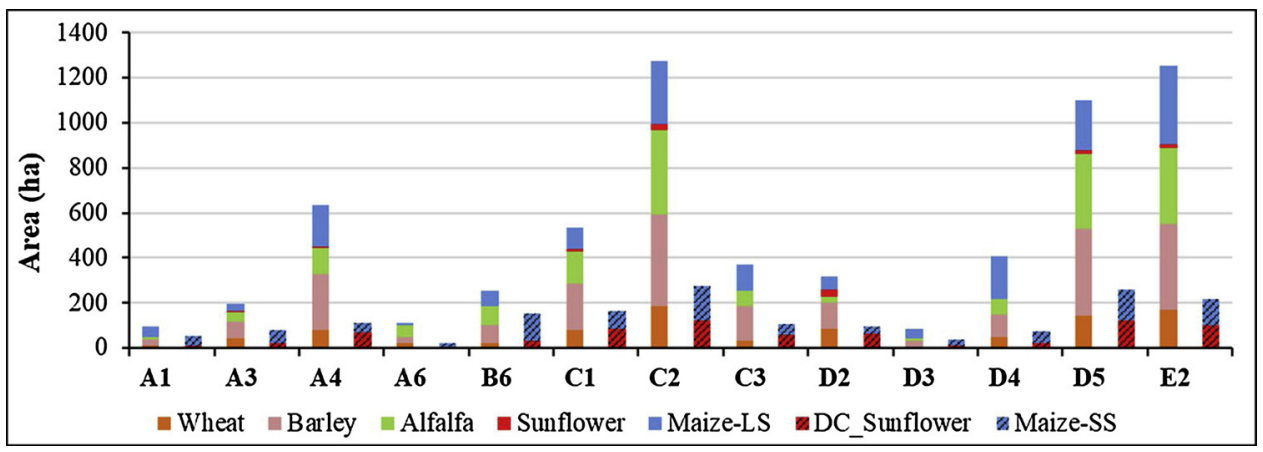

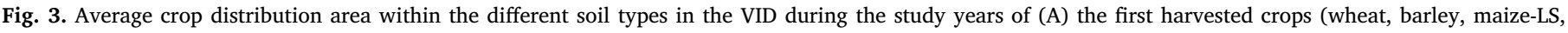
sunflower and alfalfa) and (B) the second harvested crop (DC_sunflower and maize-SS) in area of each soil total double crop area. 

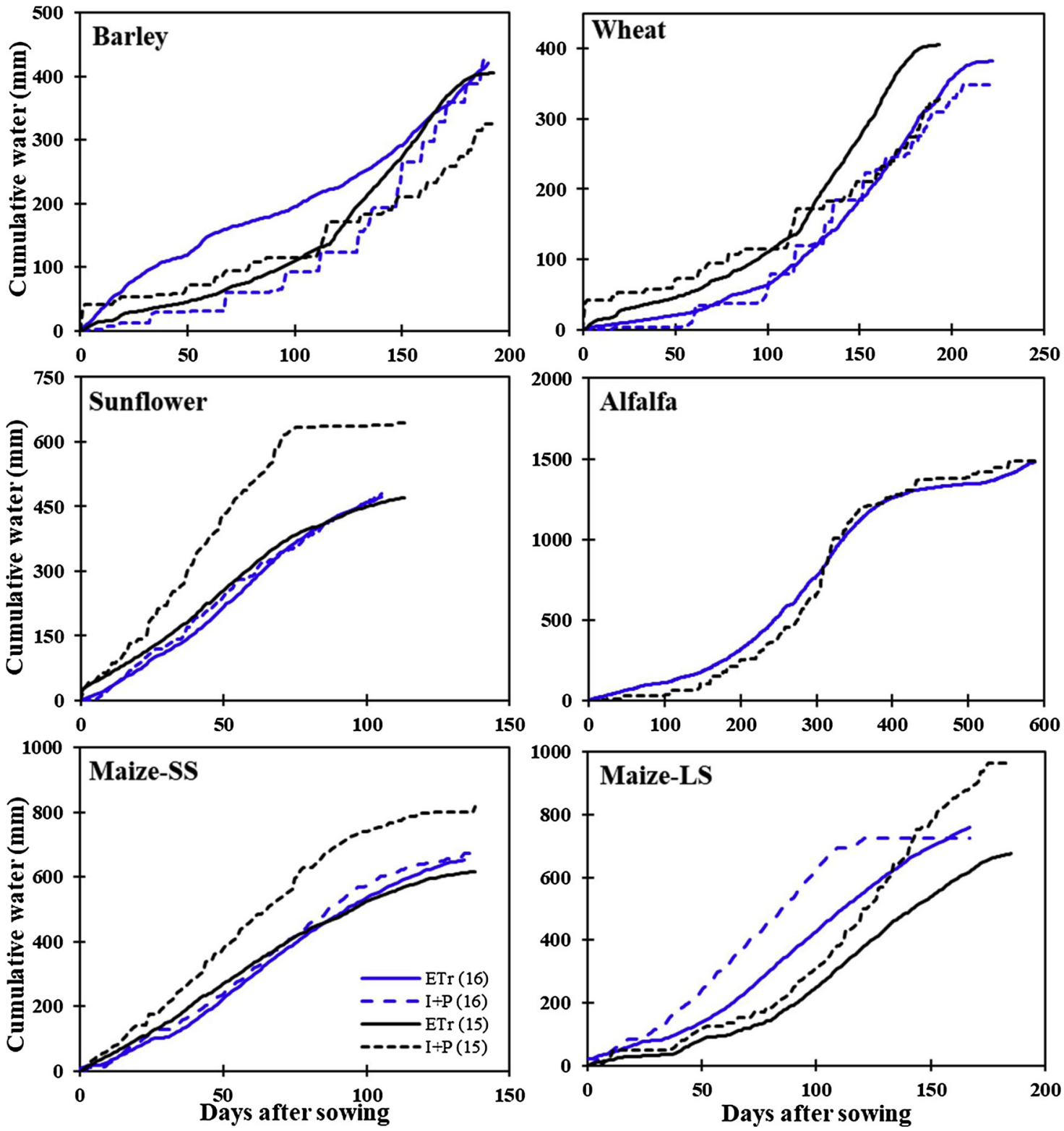

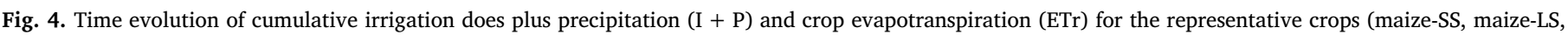
wheat, barley and sunflower) grown in VID during 2015 and 2016 hydrological years and for alfalfa in 2016.

of irrigation needs to meet the changing water demands of the plant and the moisture level of the soil.

Regarding the crop irrigation efficiency, the IE for maize-LS as well as for maize-SS was $85 \%$ and $79 \%$, respectively. A similar value of $77 \%$ was obtained for sunflower. In the case of alfalfa, the IE was $105 \%$. Barley and wheat were the most water-stressed crops during the two study years, with an IE greater than $142 \%$. These values indicated that the wheat and barley net irrigation requirements were not met. With regard to soil types in the VID, the same irrigation scheduling was observed for the different soils in both years. The IE was always higher than $101 \%$. The highest IE value was observed for soil unit D (120\%), followed by soil unit C (113\%). These values indicate that farmers did not consider the soil type when determining irrigation water depth.

These data suggest that farmers tried to optimize irrigation water use by restricting application on drought stress tolerant crops (e.g., winter wheat and barley) and by limiting water stress on droughtsensitive crops (e.g., maize). Additionally, alfalfa has a very deep root system. Nevertheless, Fig. 4 shows that the water requirements were not met during 2016, indicating that farmers applied less irrigation water to crops where yield reductions produced less damage to their respective economies.

\subsection{Model calibration and evaluation}

The calibrated genetic coefficients for maize-SS, maize-LS, wheat, Barley and sunflower are presented in Table 3. In general, the crop productivity results indicated an accurate prediction for grain yield and a reasonable simulation for vegetative biomass (Fig. 5). In particular, good agreement was observed for grain yield calibration and evaluation process concerning all crops, with a coefficient of regression greater than 0.85 between the simulated and observed values. Nonetheless, for vegetative biomass, the model was reasonably adjusted, with an $\mathrm{R}^{2}$ that varied between 0.26 and 1 . In the same context, the evaluation of vegetative biomass for wheat was poor $\left(\mathrm{R}^{2}=0.51\right)$ compared with that of barley $\left(R^{2}=0.82\right)$.

\subsubsection{Maize-SS}

The model calibration and evaluation show good results for anthesis 


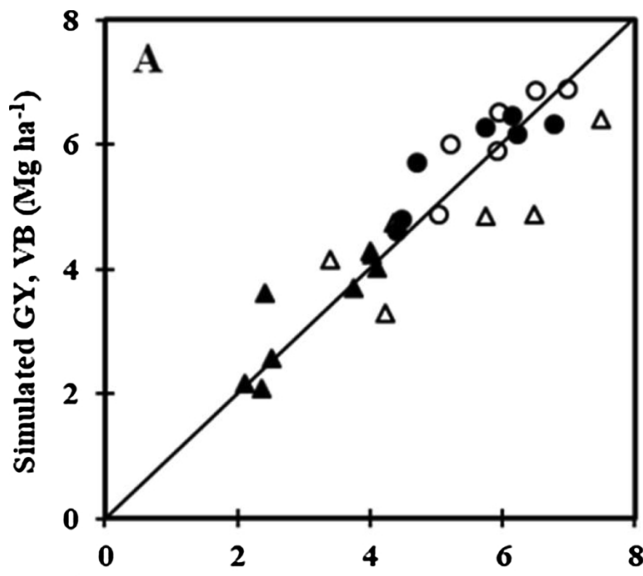

\begin{tabular}{llcc}
\cline { 3 - 4 } & & \multicolumn{2}{c}{$\mathrm{R}^{2}$} \\
\cline { 3 - 4 } & & $\begin{array}{c}\text { Grain } \\
\text { yield }\end{array}$ & $\begin{array}{c}\text { Vegetative } \\
\text { biomass }\end{array}$ \\
\hline \multirow{2}{*}{ Barley (A) } & Calibration & 0.88 & 0.85 \\
& Validation & 0.97 & 0.82 \\
\hline \multirow{2}{*}{ Wheat (B) } & Calibration & 1.00 & 1.00 \\
& Validation & 0.99 & 0.51 \\
\hline \multirow{2}{*}{ Sunflower (C) } & Calibration & 0.97 & 0.73 \\
& Validation & 0.98 & 0.55 \\
\hline \multirow{2}{*}{ Maize-LS (D) } & Calibration & 0.90 & 0.42 \\
& Validation & 0.85 & 0.78 \\
\hline \multirow{2}{*}{ Maize-SS (E) } & Calibration & 0.99 & 0.26 \\
& Validation & 0.90 & 0.21 \\
\hline
\end{tabular}
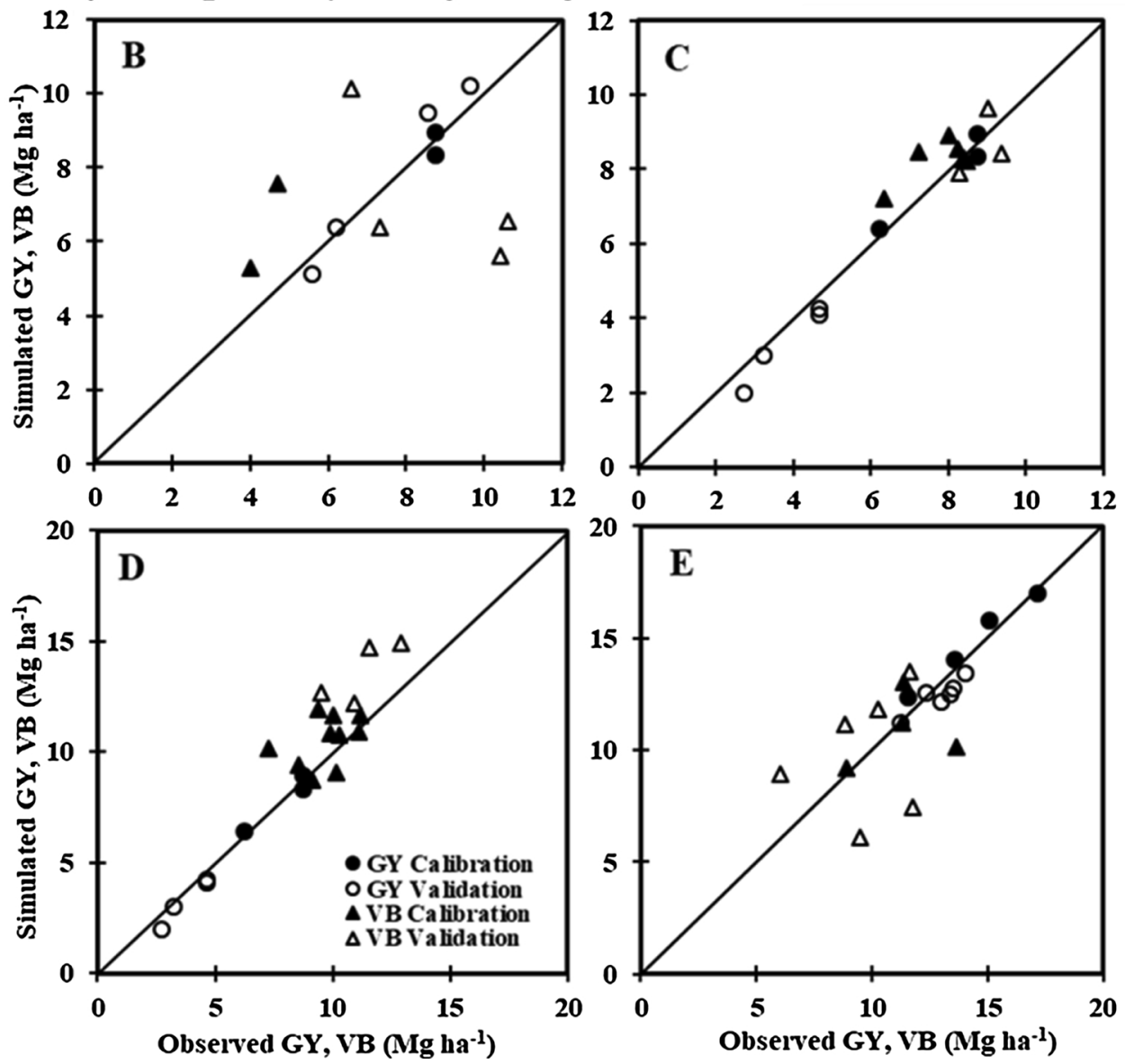

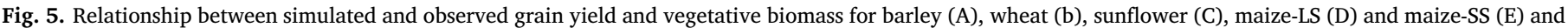
the associate Table for the coefficients of determination $\left(\mathrm{R}^{2}\right)$ for calibration and evaluation process.

and physiological maturity dates with an RMSE value less than 5 days, an nRMSE less than $8 \%$ (Table 4). Crop productivity calibration and evaluation show also good results, with an RMSE less than $622 \mathrm{~kg} \mathrm{ha}^{-1}$ and $2895 \mathrm{~kg} \mathrm{ha}^{-1}$ for grain yield and vegetative biomass, respectively. The d-statistic was higher than 0.94 for both variables. In terms of the grain $\mathrm{N}$ uptake, the model simulated this variable relatively well, with an RMSE of $43 \mathrm{~kg} \mathrm{~N} \mathrm{ha}^{-1}$ and an nRMSE of $26 \%$. Moreover, the RMSE of the vegetative $\mathrm{N}$ uptake was $59 \mathrm{~kg} \mathrm{~N}$ ha $^{-1}$, and the nRMSE was $32 \%$. In terms of the residual $\mathrm{N}$ in the soil, the results were moderate, with an RMSE of $53 \mathrm{~kg} \mathrm{~N}$ ha $^{-1}$ and a high d-statistic of 0.72 .

\subsubsection{Maize-LS}

Results of model calibration and evaluation for anthesis and physiological maturity dates were good with a RMSE less than 7 days
(Table 4). In the same way, the model calibration and evaluation performance was considered excellent for grain yield with a RMSE (nRMSE) lower than $694 \mathrm{~kg} \mathrm{ha}^{-1}(5 \%)$ and acceptable for vegetative biomass with a RMSE (nRMSE) value less than $2522 \mathrm{~kg} \mathrm{ha}^{-1}(22 \%)$. The model also overpredicted the grain $\mathrm{N}$ uptake, with an RMSE of $57 \mathrm{~kg} \mathrm{~N} \mathrm{ha}^{-1}$, while it more accurately infra-estimated the vegetative biomass $\mathrm{N}$ uptake, with an RMSE of $34 \mathrm{~kg} \mathrm{~N} \mathrm{ha}^{-1}$. In addition, the model overestimated the residual $\mathrm{N}$ in the soil, with an RMSE of $73 \mathrm{~kg} \mathrm{~N}$ $\mathrm{ha}^{-1}$. For instance, Yakoub et al. (2017) found higher RMSE values than those obtained in our results for both grain yield and total biomass, with values of $1313 \mathrm{~kg} \mathrm{ha}^{-1}$ and $3324 \mathrm{~kg} \mathrm{ha}^{-1}$, respectively. Furthermore, similar performance of the CERES-Maize model was obtained for grain yield by Liu et al. (2012) in Northeast China, with nRMSE value of $5 \%$. The results obtained by Liu et al. (2011) also 
Table 4

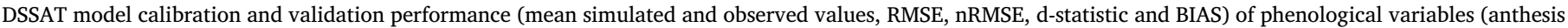

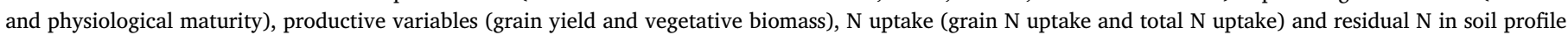
$(1.2 \mathrm{~m})$ for Maize-SS and maize hybrids.

\begin{tabular}{|c|c|c|c|c|c|c|c|}
\hline & & Mean sim & Mean obs & d-stat & BIAS & NRMSE & RMSE \\
\hline \multicolumn{8}{|l|}{ Maize-SS } \\
\hline \multirow[t]{4}{*}{ Calibration } & Anthesis (DAS) & 66 & 71 & 0.65 & -5 & 8 & 5 \\
\hline & Physiological maturity (DAS) & 141 & 139 & 0.99 & 2 & 1 & 2 \\
\hline & Grain yield $\left(\mathrm{kg} \mathrm{ha}^{-1}\right)$ & 14801 & 14341 & 0.97 & 460 & 4 & 607 \\
\hline & Vegetative biomass $\left(\mathrm{kg} \mathrm{ha}^{-1}\right)$ & 10905 & 11291 & 0.96 & -385 & 17 & 1934 \\
\hline \multirow[t]{7}{*}{ Evaluation } & Anthesis (DAS) & 68 & 65 & 0.61 & 4 & 6 & 4 \\
\hline & Physiological maturity (DAS) & 129 & 132 & 0.91 & -2 & 4 & 5 \\
\hline & Grain yield $\left(\mathrm{kg} \mathrm{ha}^{-1}\right)$ & 12452 & 12900 & 0.98 & -448 & 5 & 622 \\
\hline & Vegetative biomass $\left(\mathrm{kg} \mathrm{ha}^{-1}\right)$ & 9834 & 9651 & 0.94 & 183 & 30 & 2895 \\
\hline & Grain $N\left(\mathrm{~kg} \mathrm{ha}^{-1}\right)$ & 187 & 167 & 0.58 & 19 & 26 & 43 \\
\hline & $\mathrm{N}$ Vegetative biomass $\left(\mathrm{kg} \mathrm{ha}^{-1}\right)$ & 224 & 183 & 0.98 & 40 & 32 & 59 \\
\hline & N Residual $\left(\mathrm{kg} \mathrm{ha}^{-1}\right)$ & 51 & 40 & 0.72 & 12 & 134 & 53 \\
\hline \multicolumn{8}{|l|}{ Maize-LS } \\
\hline \multirow[t]{4}{*}{ Calibration } & Anthesis (DAS) & 93 & 94 & 0.11 & 0 & 3 & 3 \\
\hline & Physiological maturity (DAS) & 152 & 153 & -1.09 & -1 & 3 & 5 \\
\hline & Grain yield $\left(\mathrm{kg} \mathrm{ha}^{-1}\right)$ & 12459 & 12718 & 0.78 & -259 & 5 & 694 \\
\hline & Vegetative biomass $\left(\mathrm{kg} \mathrm{ha}^{-1}\right)$ & 10503 & 9695 & -0.65 & 808 & 15 & 1434 \\
\hline \multirow[t]{7}{*}{ Evaluation } & Anthesis (DAS) & 104 & 101 & 1.00 & 3 & 4 & 4 \\
\hline & Physiological maturity (DAS) & 167 & 161 & 1.00 & 6 & 4 & 7 \\
\hline & Grain yield $\left(\mathrm{kg} \mathrm{ha}^{-1}\right)$ & 12874 & 13151 & 0.88 & -277 & 5 & 679 \\
\hline & Vegetative biomass $\left(\mathrm{kg} \mathrm{ha}^{-1}\right)$ & 13612 & 11220 & 0.73 & 2392 & 22 & 2522 \\
\hline & Grain $\mathrm{N}\left(\mathrm{kg} \mathrm{ha}^{-1}\right)$ & 182 & 131 & 0.71 & 52 & 43 & 57 \\
\hline & $\mathrm{N}$ Vegetative biomass $\left(\mathrm{kg} \mathrm{ha}^{-1}\right)$ & 53 & 76 & 0.59 & -23 & 45 & 34 \\
\hline & $\mathrm{N}$ Residual $\left(\mathrm{kg} \mathrm{ha}^{-1}\right)$ & 55 & 39 & 0.39 & 17 & 191 & 73 \\
\hline
\end{tabular}

showed less accuracy for grain yield prediction, with higher RMSE $\left(1945 \mathrm{~kg} \mathrm{ha}^{-1}\right)$ and nRMSE (19.2\%) values. In terms of the $\mathrm{N}$ uptake components, our results are similar to those obtained by Yakoub et al. (2017), who found RMSE and d-statistic values of $41 \mathrm{~kg} \mathrm{~N} \mathrm{ha}^{-1}$ and 0.88, respectively. Nevertheless, Salmerón et al. (2014) found a lower RMSE of $25 \mathrm{~kg} \mathrm{~N} \mathrm{ha}^{-1}$ for grain $\mathrm{N}$ uptake. An accurate prediction of plant $\mathrm{N}$ content depends on the simulation accuracy of the total biomass and $\mathrm{N}$ concentration in the plant tissues. This result can be associated with the overestimation of the total biomass that has been described previously.

\subsubsection{Wheat}

The statistical results for calibration and evaluation for anthesis and physiological maturity dates were excellent with a RMSE less than 4 days (Table 5). The model reasonably simulated the grain yield in the calibration and validation processes with a RMSE less than $587 \mathrm{~kg} \mathrm{ha}^{-1}$. In addition, the d-statistic was higher than 0.7 for both grain yield and vegetative biomass. The high RMSE values for vegetative biomass in both calibration and validation processes (RMSE higher than $2231 \mathrm{~kg}$ $\mathrm{ha}^{-1}$ ) were due to considerable leaf losses leading to late leaf spot disease on a given plot, even though pesticides were applied. The model did not simulate these leaf losses. The model simulated well the $\mathrm{N}$ uptake in grain and vegetative biomass and residual $\mathrm{N}$ in soil (up to a depth of $120 \mathrm{~cm}$ ) with a RMSE less than $28 \mathrm{~kg} \mathrm{~N} \mathrm{ha}^{-1}$.

The performance of the model slightly reduced under current conditions, particularly at farmer plots, compared with the experimental and control plots, which is in accordance with Staggenborg and Vanderlip (2004). Andarzian et al. (2014), Dar et al. (2017) and Hundal and Prabhjyot-Kaur (1997) reported RMSE values lower than 4 days in terms of the time to anthesis and physiological maturity. Arora et al. (2007) reported an RMSE for grain yield of $800 \mathrm{~kg} \mathrm{ha}^{-1}$ and nRMSE of $25 \%$ for measured yields, which ranged between 1400 and $5100 \mathrm{~kg}$ $\mathrm{ha}^{-1}$ in semiarid subtropical environments. Timsina and Humphreys (2006) found an nRMSE of $15-17 \%$ for biomass and $7-17 \%$ for grain yield. Andarzian et al. (2014) reported an RMSE of 580 and $470 \mathrm{~kg}$ $\mathrm{ha}^{-1}$ between the simulated and observed grain and the biological yield. Similarly, Heng et al. (2000) reported RMSE values of 1110 and $1500 \mathrm{~kg} \mathrm{ha}^{-1}$ between the simulated and observed biological yields.
Dar et al. (2017) reported that the DSSAT model performed well in simulating grain yield (RMSE $=154.6 \mathrm{~kg}$ ) and biological yield $($ RMSE $=584.9 \mathrm{~kg})$. The DSSAT model $(\mathrm{V} 4.7)$ satisfactorily simulated the occurrence of vegetative stages, crop productivity, grain $\mathrm{N}$ uptake, vegetative $\mathrm{N}$ uptake and residual $\mathrm{N}$ in the soil. Nevertheless, the greater variance in the simulation of grain yield relative to that of vegetative biomass was noticed in those reported studies, and this difference could be attributed to the partitioning of simulated biomass into the different organs built in the model. However, Hundal and Prabhjyot-Kaur (1997) reported that the biomass simulations indicated the need for further examination of the factors controlling the partitioning of photosynthates during crop growth.

\subsubsection{Barley}

The CERES-Barley model calibration and evaluation results indicate a good performance of the model to simulate crop phenology variables with a nRMSE lower than 7\%, and a d-statistic higher than 0.82 for anthesis and physiological maturity, respectively (Table 5). For both grain yield calibration and evaluation, the RMSE and nRMSE were lower than $497 \mathrm{~kg} \mathrm{ha}^{-1}$ and $9 \%$, respectively. In general, good results were obtained for the grain and vegetative biomass $\mathrm{N}$ uptake variables and the soil residual $\mathrm{N}$ for both calibration and validation processes with a RMSE less than $32 \mathrm{~kg} \mathrm{~N} \mathrm{ha}{ }^{-1}$. In fact, Travasso and Magrin (1998) found similar results in his study in Argentine conditions, with an RMSE for anthesis of 5.6 days and an RMSE of grain yield of $397 \mathrm{~kg}$ $\mathrm{ha}^{-1}$.

\subsubsection{Sunflower}

For both calibration and evaluation results (Table 6), the model simulated the sunflower phenology dates reasonably well, with an RMSE (nRMSE) less than 6 days (9\%) for anthesis and less than 7 days (7\%) for physiological maturity. In addition, the model evaluation results were better than the calibration results for grain yield (RMSE: $463 \mathrm{~kg} \mathrm{ha}^{-1}$ vs. $565 \mathrm{~kg} \mathrm{ha}^{-1}$; nRMSE: $12 \%$ vs. $15 \%$ ) and vegetative biomass (RMSE: $603 \mathrm{~kg} \mathrm{ha}^{-1}$ vs. $733 \mathrm{~kg} \mathrm{ha}^{-1}$; nRMSE: $7 \%$ vs. $9 \%$ ). In terms of $\mathrm{N}$ uptake, the calibration results indicated a good agreement between the simulated and observed grain $\mathrm{N}$ uptake (RMSE: $32 \mathrm{~kg} \mathrm{~N}^{-}$ 1 , nRMSE: $27 \%$ and d-statistic: 0.74 ) and acceptable results for 
Table 5

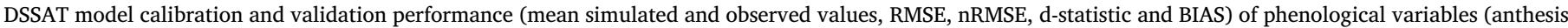

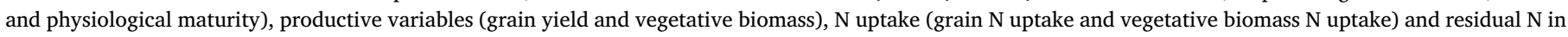
soil profile $(1.2 \mathrm{~m})$ for wheat and barley.

\begin{tabular}{|c|c|c|c|c|c|c|c|}
\hline & & Mean sim & Mean obs & d-stat & BIAS & NRMSE & RMSE \\
\hline \multicolumn{8}{|l|}{ Wheat } \\
\hline \multirow[t]{4}{*}{ Calibration } & Anthesis (DAS) & 153 & 155 & 0.99 & -2 & 1 & 2 \\
\hline & Physiological maturity (DAS) & 192 & 192 & 1.00 & 0 & 4 & 0 \\
\hline & Grain yield $\left(\mathrm{kg} \mathrm{ha}^{-1}\right)$ & 8645 & 8747 & 1.00 & -102 & 4 & 317 \\
\hline & Vegetative biomass $\left(\mathrm{kg} \mathrm{ha}^{-1}\right)$ & 6432 & 4345 & 0.72 & 2087 & 51 & 2231 \\
\hline \multirow[t]{7}{*}{ Evaluation } & Anthesis (DAS) & 156 & 155 & 0.75 & 1 & 2 & 4 \\
\hline & Physiological maturity (DAS) & 200 & 200 & 0.94 & -1 & 1 & 3 \\
\hline & Grain yield $\left(\mathrm{kg} \mathrm{ha}^{-1}\right)$ & 7804 & 7503 & 0.98 & 302 & 8 & 587 \\
\hline & Vegetative biomass $\left(\mathrm{kg} \mathrm{ha}^{-1}\right)$ & 7165 & 8735 & 0.95 & -1570 & 42 & 3635 \\
\hline & Grain $N\left(\mathrm{~kg} \mathrm{ha}^{-1}\right)$ & 168 & 167 & 1.00 & 0 & 7 & 12 \\
\hline & Vegetative biomass $\mathrm{N}\left(\mathrm{kg} \mathrm{ha}^{-1}\right)$ & 32 & 39 & 0.91 & -7.053 & 56 & 22 \\
\hline & Residual N (kg ha ${ }^{-1}$ ) & 35 & 23 & 0.8 & 12.217 & 122 & 28 \\
\hline \multicolumn{8}{|l|}{ Barley } \\
\hline \multirow[t]{4}{*}{ Calibration } & Anthesis (DAS) & 160 & 159 & 0.95 & 0 & 2 & 4 \\
\hline & Physiological maturity (DAS) & 192 & 190 & 0.98 & 3 & 1 & 3 \\
\hline & Grain yield $\left(\mathrm{kg} \mathrm{ha}^{-1}\right)$ & 5758 & 5499 & 0.88 & 379 & 9 & 497 \\
\hline & Vegetative biomass $\left(\mathrm{kg} \mathrm{ha}^{-1}\right)$ & 3206 & 3039 & 0.92 & 167 & 16 & 478 \\
\hline \multirow[t]{7}{*}{ Evaluation } & Anthesis (DAS) & 164 & 168 & 0.87 & -4 & 3 & 5 \\
\hline & Physiological maturity (DAS) & 198 & 193 & 0.82 & 5 & 4 & 7 \\
\hline & Grain yield $\left(\mathrm{kg} \mathrm{ha}^{-1}\right)$ & 6681 & 6605 & 0.99 & 75 & 7 & 464 \\
\hline & Vegetative biomass $\left(\mathrm{kg} \mathrm{ha}^{-1}\right)$ & 4655 & 5099 & 0.91 & -443 & 18 & 934 \\
\hline & Grain $N\left(\mathrm{~kg} \mathrm{ha}^{-1}\right)$ & 88 & 76 & 0.69 & 6 & 42 & 32 \\
\hline & Vegetative biomass $\mathrm{N}\left(\mathrm{kg} \mathrm{ha}^{-1}\right)$ & 25 & 24 & 0.81 & 0 & 32 & 8 \\
\hline & Residual $\mathrm{N}\left(\mathrm{kg} \mathrm{ha}^{-1}\right)$ & 31 & 38 & 0.70 & -16 & 67 & 26 \\
\hline
\end{tabular}

vegetative biomass $\mathrm{N}$ uptake (RMSE: $52 \mathrm{~kg} \mathrm{~N}$ ha $^{-1}$ and d-statistic: 0.68 ). A reasonable performance of residual $\mathrm{N}$ was observed, with an RMSE of $43 \mathrm{~kg} \mathrm{~N} \mathrm{ha}^{-1}$. Since no studies have been published using the recently introduced CROPGRO sunflower module in last DSSAT version (v4.7), the present results are compared to those obtained with the OILCROPSUN module (i.e., an older DSSAT version). Thus, Ashfaq et al. (2013) described that the OILCROP-SUN model estimated anthesis date and maturity date with errors ranging from $1.32 \%$ to $5.63 \%$ and $0.87 \%$ to $8.41 \%$, respectively. Lower RMSE values for anthesis (6.9 days), maturity date $\left(7.7\right.$ days), achene yield $\left(19.6 \mathrm{t} \mathrm{ha}^{-1}\right)$ and total dry matter (17.5 $\mathrm{t} \mathrm{ha}^{-1}$ ) were also reported by Rinaldia et al. (2003), who used the OILCROP-SUN in Italy. Awais et al. (2017) obtained a time course simulation of total dry matter, and the RMSE ranged between $201 \mathrm{~kg}$ $\mathrm{ha}^{-1}$ and $559 \mathrm{~kg} \mathrm{ha}^{-1}$. The corresponding values of these parameters in model validation were $285-450 \mathrm{~kg} \mathrm{ha}^{-1}$ for the RMSE and 0.97-0.99 for the d-statistic.

Therefore, a good performance of the DSSAT model was demonstrated based on the good statistical fit for the different crops in the VID and especially for the growth stages and grain yield. In addition, satisfactory results were obtained for the vegetative biomass, $\mathrm{N}$ uptake parameters and reasonable accuracy for residual $\mathrm{N}$ in the soil.

\subsection{Irrigation scenario assessment}

The irrigation scenario results are presented as detailed figures for maize-SS (warm season plant) and wheat (cool season plant). For the remaining crops (maize-LS, barley, sunflower and alfalfa), the simulation outputs are summarized in Table 7.

\subsubsection{Crop yield and irrigation scheduling}

Both the maize-SS and maize-LS hybrid simulation results show that there were no differences in the grain yield between the current irrigation practices and the optimal irrigation among different soil types during the 2015 and 2016 seasons (Fig. 6A and Table 7). Averaging across different soils and years, the simulated maize-SS crop yield with the current irrigation management was $11,072 \mathrm{~kg} \mathrm{ha}^{-1}$, while with the optimal irrigation, it was slightly higher at $11,399 \mathrm{~kg} \mathrm{ha}^{-1}$. In addition, in the case of maize-LS, the average crop yield was $12,453 \mathrm{~kg} \mathrm{ha}^{-1}$ under the current irrigation management, while under optimal irrigation, it was $12,450 \mathrm{~kg} \mathrm{ha}^{-1}$ (Table 7). In terms of the seasonal irrigation depths and number of applications, these values were consistently lower under the optimal irrigation scenario than under the current irrigation schedule for both considered maize hybrids across all soil types

Table 6

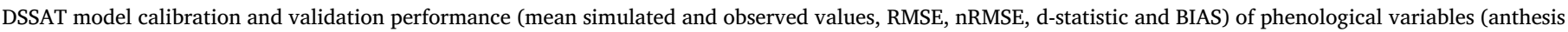

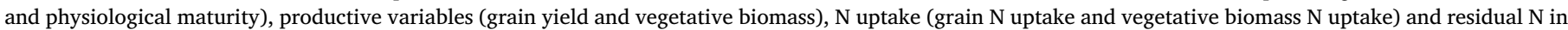
soil profile $(1.2 \mathrm{~m})$ for Sunflower.

\begin{tabular}{|c|c|c|c|c|c|c|c|}
\hline Sunflower & & Mean sim & Mean obs & d-stat & BIAS & NRMSE & RMSE \\
\hline \multirow[t]{4}{*}{ Calibration } & Anthesis (DAS) & 56 & 57 & 0.25 & -1 & 3 & 2 \\
\hline & Physiological maturity (DAS) & 105 & 107 & -0.06 & -2 & 3 & 3 \\
\hline & Grain yield $\left(\mathrm{kg} \mathrm{ha}^{-1}\right)$ & 4203 & 3779 & 0.91 & 424 & 15 & 565 \\
\hline & Vegetative biomass $\left(\mathrm{kg} \mathrm{ha}^{-1}\right)$ & 8280 & 7759 & 0.75 & 521 & 9 & 733 \\
\hline \multirow[t]{7}{*}{ Evaluation } & Anthesis (DAS) & 55 & 61 & 0.74 & -6 & 9 & 6 \\
\hline & Physiological maturity (DAS) & 99 & 106 & 0.74 & -7 & 7 & 7 \\
\hline & Grain yield $\left(\mathrm{kg} \mathrm{ha}^{-1}\right)$ & 3540 & 3821 & 0.91 & -282 & 12 & 463 \\
\hline & Vegetatif biomass $\left(\mathrm{kg} \mathrm{ha}^{-1}\right)$ & 8540 & 8780 & 0.71 & 380 & 7 & 603 \\
\hline & Grain $N\left(\mathrm{~kg} \mathrm{ha}^{-1}\right)$ & 92 & 117 & 0.74 & -26 & 27 & 32 \\
\hline & Vegetative biomass $\mathrm{N}\left(\mathrm{kg} \mathrm{ha}^{-1}\right)$ & 109 & 65 & 0.68 & 44 & 80 & 52 \\
\hline & Residual N (kg ha $\left.{ }^{-1}\right)$ & 19 & 56 & 0.73 & -37 & 77 & 43 \\
\hline
\end{tabular}


Table 7

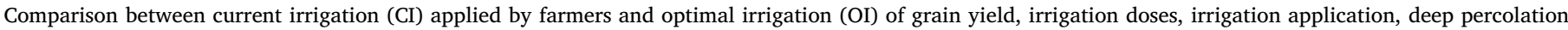

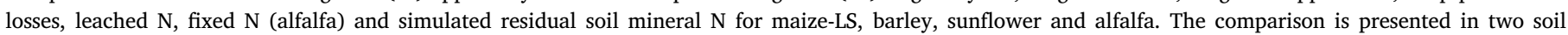
categories shallow and/or low permeability soils (B6, A4 and D4) and high permeability soils (E2, C1, C2, C3 and D5) during 2015 and 2016 seasons.

\begin{tabular}{|c|c|c|c|c|c|c|c|c|c|c|c|c|c|c|}
\hline & & \multicolumn{2}{|c|}{ Grain yield $\left(\mathrm{kg} \mathrm{ha}^{-1}\right)$} & \multicolumn{2}{|c|}{$\begin{array}{l}\text { Irrigation events } \\
\text { number }\end{array}$} & \multicolumn{2}{|c|}{$\begin{array}{l}\text { Irrigation depth } \\
(\mathrm{mm})\end{array}$} & \multicolumn{2}{|c|}{$\begin{array}{l}\text { Leached N (kg N } \\
\left.\text { ha }^{-1}\right)\end{array}$} & \multicolumn{2}{|c|}{$\begin{array}{l}\text { Deep percolation } \\
\text { losses }(\mathrm{mm})\end{array}$} & \multicolumn{2}{|c|}{$\mathrm{N}$ soil $\left(\mathrm{kg} \mathrm{N} \mathrm{ha}^{-1}\right)$} & \multirow{2}{*}{$\begin{array}{l}\mathrm{N}_{2} \text { fixed } \\
\mathrm{kg} \mathrm{ha}^{-1} \\
2016\end{array}$} \\
\hline & & 2015 & 2016 & 2015 & 2016 & 2015 & 2016 & 2015 & 2016 & 2015 & 2016 & 2015 & 2016 & \\
\hline & & \multicolumn{13}{|c|}{ Maize-LS } \\
\hline \multirow{2}{*}{$\begin{array}{l}\text { Shallow and/or high } \\
\text { permeability soil (B6, } \\
\text { A4, D4) }\end{array}$} & $\mathrm{CI}$ & 12584 & 12106 & 95 & 110 & 766 & 732 & 108 & 17 & 176 & 123 & 71 & 152 & - \\
\hline & OI & 12584 & 12260 & 70 & 92 & 526 & 697 & 12 & 17 & 111 & 123 & 154 & 146 & - \\
\hline \multirow{3}{*}{$\begin{array}{l}\text { Low permeability soil (E2, } \\
\text { C1, C2, C3, D5) }\end{array}$} & $\mathrm{CI}$ & 12784 & 12250 & 95 & 110 & 766 & 732 & 9 & 1 & 24 & 7 & 112 & 114 & - \\
\hline & OI & 12631 & 12303 & 77 & 92 & 569 & 685 & 0 & 1 & 5 & 7 & 128 & 114 & - \\
\hline & & \multicolumn{13}{|c|}{ Sunflower } \\
\hline \multirow{2}{*}{$\begin{array}{l}\text { Shallow and/or high } \\
\text { permeability soil (B6, } \\
\text { A4, D4) }\end{array}$} & $\mathrm{CI}$ & 4148 & 2804 & 60 & 68 & 492 & 456 & 90 & 33 & 192 & 69 & 4 & 40 & - \\
\hline & OI & 4110 & 4207 & 34 & 59 & 229 & 466 & 36 & 33 & 69 & 69 & 3 & 5 & - \\
\hline \multirow{3}{*}{$\begin{array}{l}\text { Low permeability soil (E2, } \\
\text { C1, C2, C3, D5) }\end{array}$} & $\mathrm{CI}$ & 4137 & 2326 & 60 & 69 & 486 & 458 & 9 & 0 & 45 & 0 & 4 & 67 & - \\
\hline & OI & 4037 & 4283 & 51 & 72 & 380 & 562 & 0 & 0 & 0 & 0 & 5 & 10 & - \\
\hline & & Barley & & & & & & & & & & & & \\
\hline \multirow{2}{*}{$\begin{array}{l}\text { Shallow and/or high } \\
\text { permeability soil (B6, } \\
\text { A4, D4) }\end{array}$} & $\mathrm{CI}$ & 7062 & 4851 & 24 & 35 & 253 & 248 & 8 & 52 & 69 & 132 & 61 & 67 & - \\
\hline & OI & 8845 & 8103 & 9 & 42 & 260 & 276 & 62 & 37 & 128 & 110 & 18 & 54 & - \\
\hline \multirow{4}{*}{$\begin{array}{l}\text { Low permeability soil (E2, } \\
\text { C1, C2, C3, D5) }\end{array}$} & $\mathrm{CI}$ & 6874 & 5175 & 24 & 35 & 252 & 248 & 1 & 7 & 44 & 76 & 90 & 106 & - \\
\hline & OI & 9430 & 8472 & 8 & 42 & 279 & 286 & 8 & 3 & 53 & 41 & 31 & 64 & - \\
\hline & & Alfalfa & & & & & & & & & & & & \\
\hline & & 2016 & & 2016 & & 2016 & & 2016 & & 2016 & & 2016 & & 2016 \\
\hline \multirow{2}{*}{$\begin{array}{l}\text { Shallow and/or high } \\
\text { permeability soil (B6, } \\
\text { A4, D4) }\end{array}$} & $\mathrm{CI}$ & 15587 & & 91 & & 793 & & 0.5 & & 21 & & 7 & & 866 \\
\hline & OI & 17824 & & 169 & & 1181 & & 0.3 & & 12 & & 4 & & 939 \\
\hline \multirow{2}{*}{$\begin{array}{l}\text { Low permeability soil (E2, } \\
\text { C1, C2, C3, D5) }\end{array}$} & CI & 15873 & & 91 & & 793 & & 0.0 & & 0 & & 7 & & 924 \\
\hline & OI & 18154 & & 162 & & 1118 & & 0.0 & & 0 & & 5 & & 1013 \\
\hline
\end{tabular}

and studied years (Fig. 6B and C; Table 7). In the case of maize-SS, the optimal irrigation schedule could reduce irrigation depths by $194 \mathrm{~mm}$ (i.e., $27 \%$ less than current irrigation depth) and irrigation event numbers by 36 applications (i.e., 33\% less than current irrigation events). The coefficient of variation of the optimal irrigation depth simulated among the different soils was $4 \%$ for 2015 and 2016, while the farmers applied the same irrigation depth. For maize crops, local farmers irrigated $128 \mathrm{~mm}$ more than the crop water requirement (Table 7). As a result, optimal irrigation could have reduced the seasonal irrigation depth and number of applications by $17 \%$ and $19 \%$ for 2015 and 2016, respectively. These results indicate that, for both maize hybrids, farmer irrigation in the considered fields was not properly scheduled in terms of irrigation timing and depth, and the soil water holding properties were not considered for scheduling irrigation.

Compared to the maize-LS crop scenarios, different results were observed for wheat, i.e., the farmers' irrigation practices were deficient. As mentioned previously, farmers tented to apply only supplemental irrigation for wheat crops, which resulted in a period of water stress during both cropping seasons. For that reason, a significant difference in grain yield was observed between the different irrigation management schedules, with an average difference of $1516 \mathrm{~kg} \mathrm{ha}^{-1}$ (Fig. 7A). The potential crop yield predicted with the optimal irrigation schedule was $7848 \mathrm{~kg} \mathrm{ha}^{-1}$ and $7329 \mathrm{~kg} \mathrm{ha}^{-1}$, for the average of all soil types for the 2015 and 2016 seasons, respectively. Meanwhile, the simulated crop yield by current irrigation practices was lower, with 6150 and $5827 \mathrm{~kg} \mathrm{ha}^{-1}$ for 2015 and 2016, respectively. Nonetheless, the application of the optimal irrigation schedule demonstrated the need to increase the seasonal irrigation depth (for both years) and the number of irrigation events in 2016 and decrease the number of irrigation events in 2015 (Fig. 7B and C). On average (soil types and two crop seasons), a 156-mm increase in the water irrigation depth during crop seasons can increase production by $25 \%$. Likewise, the barley crop yield was always higher with the optimal irrigation schedule than with the current irrigation schedule among soil types and both cropping seasons
(Table 7). By averaging the soil types and years, the simulated crop yield was $5836 \mathrm{~kg} \mathrm{ha}^{-1}$ with the current irrigation situation and $8709 \mathrm{~kg}$ $\mathrm{ha}^{-1}$ with the optimal irrigation situation (approximately 33\% of crop yield increase). In addition, the optimal irrigation depth was $277 \mathrm{~mm}$, while the farmers applied only $250 \mathrm{~mm}$. Furthermore, the number of irrigation events can be reduced by $14 \%$ under the optimal irrigation schedule. Among all soil types, the number of irrigation applications was higher in 2016 (42 events on average) than in 2015 (9 events on average), although similar irrigation depths were applied for the tow irrigation management (Table 7). These results emphasize the timing and dose of irrigation are important for achieving high yields and sustainable irrigation use.

In the case of sunflower, there was no difference in crop production between the different soil types in 2015 (Table 7). When averaging the different soils, the grain yield was $4141 \mathrm{~kg} \mathrm{ha}^{-1}$ and $4064 \mathrm{~kg} \mathrm{ha}^{-1}$ under the current and optimal irrigation schedules, respectively. In the other region, the optimum irrigation varied between $206 \mathrm{~mm}$ (D4 soil type) and $568 \mathrm{~mm}$ (C2 soil type). However, in the 2016 season, the crop production under the optimal irrigation schedule was higher $(4254 \mathrm{~kg}$ $\mathrm{ha}^{-1}$ ) than that obtained under the current irrigation schedule $(1556 \mathrm{~kg}$ $\left.\mathrm{ha}^{-1}\right)$. The low production values observed in 2016 under the current irrigation schedule were due to water stress caused by insufficient irrigation and/or inadequate irrigation timing. Additionally, the results indicate that less optimum irrigation depth variation was observed between the different soil types (i.e., from $438 \mathrm{~mm}$ to $610 \mathrm{~mm}$ ) during 2016 (Table 7). As a result, potential sunflower production can be obtained by applying a seasonal irrigation depth of $526 \mathrm{~mm}$ instead of $457 \mathrm{~mm}$, which is the current amount applied by local farmers. In 2015, irrigation water could be reduced by $34 \%$ under the optimal irrigation schedule, while still maintaining similar production. In addition, the number of irrigation events could be reduced from 65 applications under current irrigation to 56 applications under optimal irrigation. These results also emphasize the importance of irrigation scheduling in achieving potential yield. 


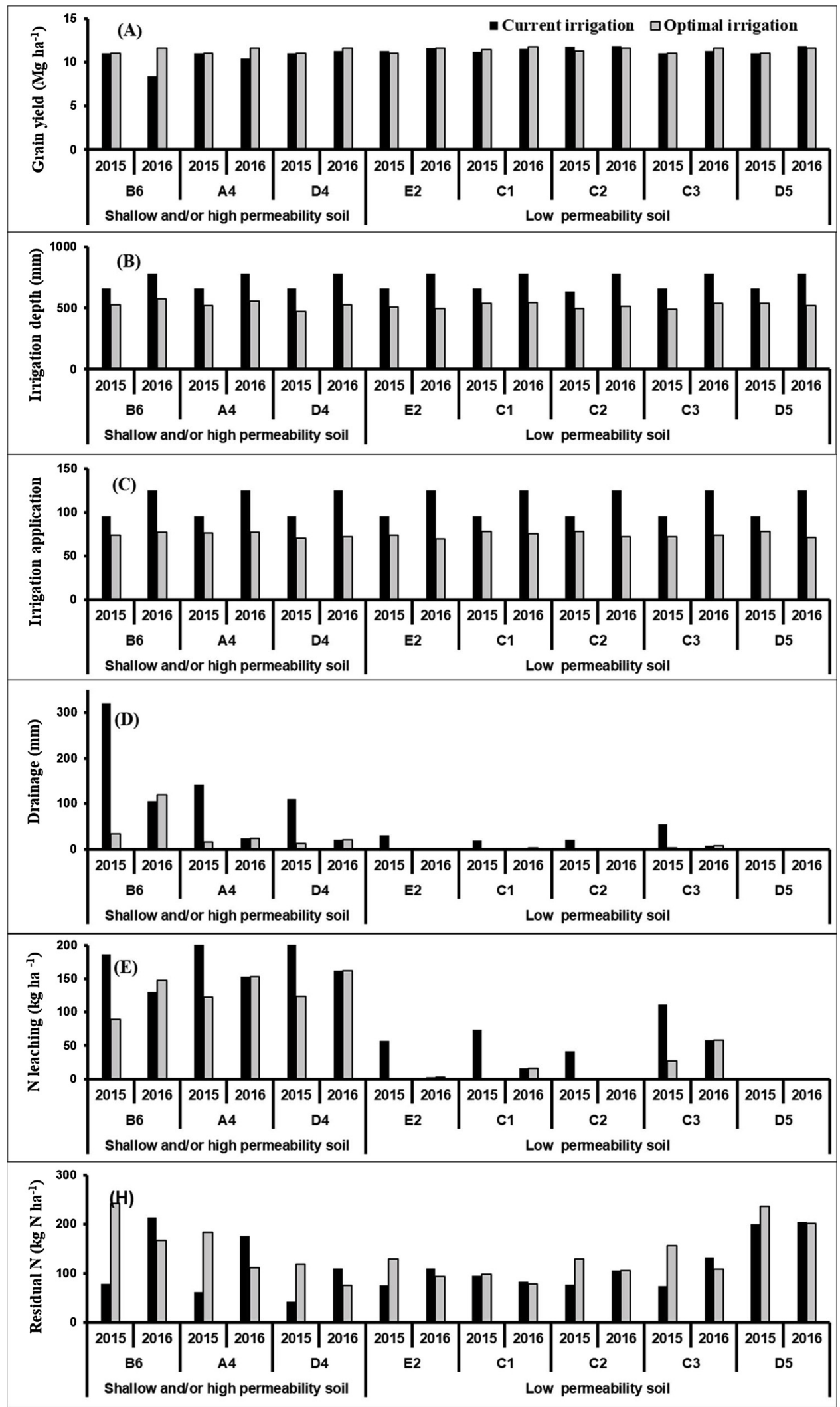

Fig. 6. Comparison between current irrigation applied by farmers and optimal irrigation of (A) grain yield (B) irrigation doses, (C) irrigation application, (D) drainage, (E) simulated $\mathrm{N}$ leached during the growing season and (F) simulated residual soil mineral $\mathrm{N}$ for maize-SS. The comparisons are presented for the eight different soil types in the VID (E2, C2, D5, A4, C1, D4, B6 and C3) during 2015 and 2016 cropping period.

Finally, the alfalfa results show that, on average, the total simulated harvested herbage was higher under the optimal irrigation $(18,030 \mathrm{~kg}$ $\mathrm{ha}^{-1}$ ) than under the current irrigation $\left(15,765 \mathrm{~kg} \mathrm{ha}^{-1}\right)$. This behavior was observed for all the soil types in the VID. The seasonal irrigation depths and the number of application events were higher under the optimal irrigation (Table 7). Therefore, to attain maximum 


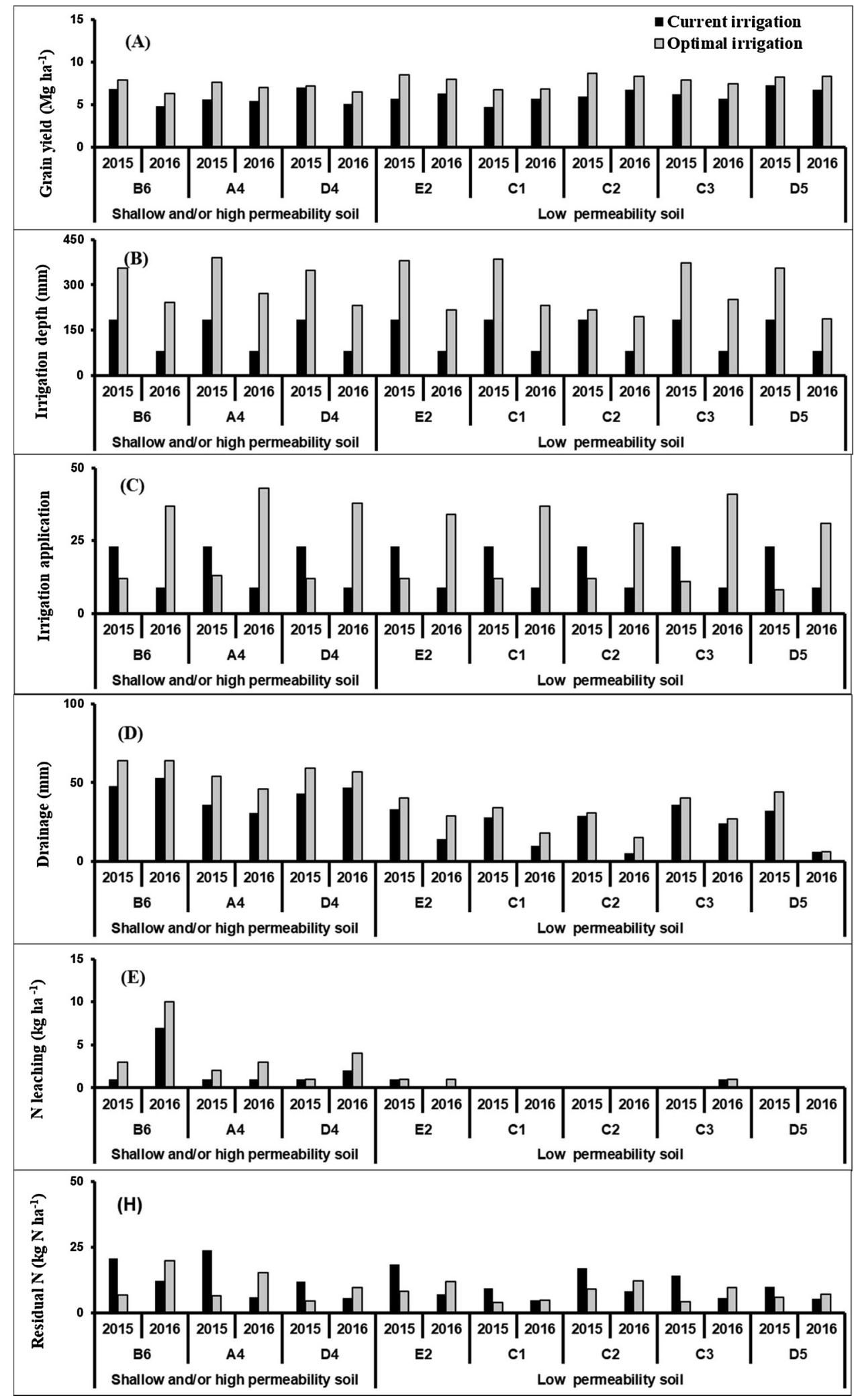

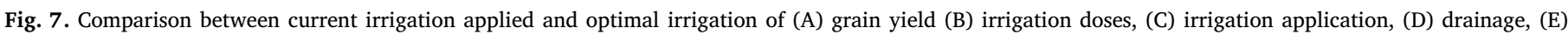

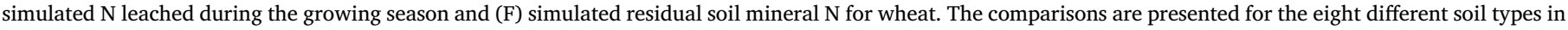
the VID (E2, C2, D5, A4, C1, D4, B6 and C3) during 2015 and 2016 cropping seasons.

crop yield, farmers should apply an average of an additional irrigation depth of $348 \mathrm{~mm}$. This additional amount of irrigation water seems important; thus, an economic analysis should be performed to determine the farmers' net benefit of introducing the optimum irrigation schedule for alfalfa in the VID.

Finally, after averaging the different soil types and years, the optimal irrigation could reduce irrigation depth by $27 \%, 17 \%$ and $16 \%$ for maize-SS, maize-LS, and sunflower, respectively. In the case of alfalfa, 
barley and wheat, an increase in water depths of $34 \%, 10 \%$ and $54 \%$, respectively, allow the potential production to be obtained while reducing environmental impacts.

\subsubsection{Deep percolation losses}

After averaging among the different soil types and the two-crop seasons, the optimal irrigation schedule could reduce deep percolation losses by $70 \%$ and $26 \%$ for maize-SS and maize-LS, respectively. For both maize hybrids, deep percolation losses were variable in the VID depending on the soil proprieties (e.g., holding capacity and texture). The simulation outputs highlighted two soil categories. The first group is characterized by low deep percolation losses (related to high holding capacity and finer texture), such as E2, C2, D5 and C1, in which the deep percolation losses were lower than $30 \mathrm{~mm}$ for maize-SS and lower than $23 \mathrm{~mm}$ for maize-LS during 2015 and 2016 (Fig. 6D; Table 7). These soils are more adequate for low irrigation frequency, which is in concordance with Aznar et al. (2013). Nevertheless, the remaining soils, such as A4, D4, B6 (shallow and high permeability soils) and C3 (one of low permeably soil case), demonstrating high deep percolation losses ranging from 35 to $190 \mathrm{~mm}$ for maize hybrids. For instance, the B6 soil presented a remarkably high amount of drainage of $321 \mathrm{~mm}$ in 2015 in maize-SS, while the optimal irrigation was $34 \mathrm{~mm}$.

Nonetheless, for the barley crops, the deep percolation losses were slightly lower with the optimal irrigation schedule, even though the irrigation depths were $10 \%$ lower than those of the current irrigation schedule.

After averaging all soil types, the deep percolation losses were $54 \mathrm{~mm}$ and $97 \mathrm{~mm}$ in 2015 and 2016, respectively, under the current irrigation schedule and $81 \mathrm{~mm}$ and $67 \mathrm{~mm}$ in 2015 and 2016, respectively, under the optimal irrigation schedule. B6 and D4 presented a high level of drainage, particularly in 2016. In the case of wheat, deep percolation losses were, on average, $10 \mathrm{~mm}$ higher under the optimal irrigation schedule (Fig. 7D). In the case of sunflower, the adjusted irrigation could reduce deep percolation losses by an average of $39 \mathrm{~mm}$ $(59 \%)$. Considering the different types of soil under the current irrigation cases, the results indicate that the deep percolation losses were more pronounced, reaching $200 \mathrm{~mm}$ in 2015, particularly for A4, D4, B6 and C3 (Table 7). In the 2016 season, the optimal irrigation schedule could have reduced $59 \%$ of drainage, with a reduction of $16 \%$ in the total water irrigation and a yield increase of $73 \%$.

As mentioned previously, the alfalfa crops suffered from slight water stress. For that reason, irrigation water losses did not occur with the current irrigation schedule for most soils except for A4 and B6, where the deep percolation was always higher than that under optimal irrigation. However, for the D4 soil, drainage was present only under the optimal irrigation schedule (Table 7).

For instance, after averaging different soil types and years, the optimal irrigation could reduce the deep percolation by $71 \%, 26 \%, 59 \%$, $5 \%$ and $42 \%$ for maize-SS, maize-LS, sunflower, barley and alfalfa, respectively.

\subsection{3. $N$ losses and residual soil $N$}

As $\mathrm{N}$ is governed by water, $\mathrm{N}$ that leaches from saturated soils is proportional to deep percolation losses. It is important to mention that the leached $\mathrm{N}$ values presented in this study correspond to the crop growing season. The results indicate that the optimal irrigation practices can reduce the leached $\mathrm{N}$ by $34 \%$ on average across soil types and years in maize-SS fields. This reduction was more pronounced in 2015, in which the average of leached $\mathrm{N}$ among different soils was $112 \mathrm{~kg} \mathrm{~N}$ $\mathrm{ha}^{-1}$ under the current irrigation schedule and $45 \mathrm{~kg} \mathrm{~N} \mathrm{ha}^{-1}$ under the optimal irrigation schedule. Moreover, the $\mathrm{N}$ losses were higher than $187 \mathrm{~kg} \mathrm{~N}^{-1}$ for the A4, D4, and B6 soils (Fig. 6E), and they reached $219 \mathrm{~kg} \mathrm{~N} \mathrm{ha}^{-1}$ for the D4 soil in 2015 . Nonetheless, negligible leached $\mathrm{N}$ was observed for E2, C2 and D5 in both years. Relating to the maize hybrid, negligible leached $\mathrm{N}$ was observed in the E2, C2, D5, C3 and C1 soils (because of low deep percolation losses). Nevertheless, for the A4,
D4 and B6 soils, the leached $\mathrm{N}$ was always higher under the current irrigation schedule than under the optimal irrigation schedule. In particular, the highest amounts of leached $\mathrm{N}$ were observed in the B6 soil, which is shallow soil (60-cm depth). In terms of the residual $\mathrm{N}$ in soil for maize-SS (Fig. 6H), the results indicated a high amount of $\mathrm{N}$ with both irrigation management schedules. After averaging all soil types in the 2015 season, the residual $\mathrm{N}$ in the soil was 88 and $162 \mathrm{~kg} \mathrm{~N} \mathrm{ha}^{-1}$ with the current irrigation and optimal irrigation, respectively. In contrast, in the 2016 season, the average residual $\mathrm{N}$ in the soil was higher with the current irrigation of $142 \mathrm{~kg} \mathrm{~N} \mathrm{ha}^{-1}$, whereas the optimal irrigation was $117 \mathrm{~kg} \mathrm{~N} \mathrm{ha}^{-1}$. Regarding the maize-LS crop, the results indicate that the residual $\mathrm{N}$ was slightly higher under the optimal irrigation schedule (Table 7). After averaging all considered soil types and cropping seasons, the residual $\mathrm{N}$ values were 113 and $132 \mathrm{~kg} \mathrm{~N}$ ha $^{-1}$ under the current irrigation and the optimal irrigation schedules, respectively.

In the case of wheat, the leached $\mathrm{N}$ was lower than $10 \mathrm{~kg} \mathrm{~N}^{-1}$ regardless of the soil type and irrigation management (Fig. 7E). After averaging the soil types and years, the leached $\mathrm{N}$ was 1 and $2 \mathrm{~kg} \mathrm{~N}^{-1}$ with the current irrigation and optimal irrigation management, respectively. The low values of leached $\mathrm{N}$ under the current irrigation were due to the low drainage resulting from water stress during the cropping seasons. The different soils in the VID demonstrated variable amounts of residual $\mathrm{N}$ in the soil (Fig. $7 \mathrm{H}$ ). On average, the residual $\mathrm{N}$ in the soil was $27 \%$ lower under optimal irrigation than under current irrigation. In contrast to the 2016 season, the residual $\mathrm{N}$ was higher in the case of the current irrigation among all the different soil in the 2015 season.

For barley, on average, the value of leached $\mathrm{N}$ was $14 \mathrm{~kg} \mathrm{~N}^{\mathrm{N}} \mathrm{a}^{-1}$ with the current irrigation and $22 \mathrm{~kg} \mathrm{~N} \mathrm{ha}^{-1}$ with the optimal irrigation. Similar to wheat, water stress was the main reason for the low value of leached $\mathrm{N}$ under the current irrigation. The residual $\mathrm{N}$ in the soil was always higher with the current irrigation and more accentuated in E2, C2 and D5 (Table 7). On average, the residual $\mathrm{N}$ was $85 \mathrm{~kg} \mathrm{~N}$ $\mathrm{ha}^{-1}$ under the framers' management and $43 \mathrm{~kg} \mathrm{~N}^{-1}$ under the optimal irrigation.

Likewise, for sunflower, the value of $\mathrm{N}$ leaching was higher with the current irrigation and more pronounced in A4, D4 and B6 (Table 7). For $\mathrm{E} 2, \mathrm{C} 2, \mathrm{D} 5, \mathrm{~N}$ leaching varied from 0 to $4 \mathrm{~kg} \mathrm{~N} \mathrm{ha}^{-1}$. The residual $\mathrm{N}$ in the soil was $80 \%$ higher with the current irrigation than with the optimal irrigation.

For alfalfa, the leached $\mathrm{N}$ was almost absent in the different soils, considering the optimal irrigation had low values that did not exceed

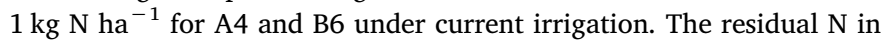
the soil was higher with the current irrigation for the different soil, and the values did not exceed $10 \mathrm{~kg} \mathrm{~N} \mathrm{ha}^{-1}$ in either irrigation management scenario (Table 7). On average, the residual $\mathrm{N}$ was 7 and $4 \mathrm{~kg} \mathrm{ha}^{-1}$ with the current and optimal irrigation, respectively. Moreover, a new parameter was considered, which is the fixed $\mathrm{N}$, a specific characteristic for legumes such as alfalfa. All the different soils represented higher values under the optimal irrigation than under the current irrigation. On average, the fixed $\mathrm{N}$ was 902 and $985 \mathrm{~kg} \mathrm{~N} \mathrm{ha}^{-1}$ under the current and optimal irrigation scenarios, respectively. However, the fixation process was less pronounced in the D5, A4 and B6 soils under both irrigation management schedules (Table 7).

After averaging the different soil types and years, the optimal irrigation schedule could reduce the $\mathrm{N}$ losses by $34 \%, 78 \%$ and $52 \%$ for maize-SS, maize-LS, and sunflower, respectively. After averaging the different soil types and years, the optimal irrigation could reduce the residual $\mathrm{N}$ by $23 \%, 49 \%, 80 \%$ and $38 \%$ for wheat, barley, sunflower and alfalfa, respectively.

\subsection{Irrigation water use sustainability in the VID}

Sustainable water management in agriculture aims to match water availability and water needs in terms of quantity and quality and in space and time with acceptable environmental impact. The results of 
A) Current irrigation
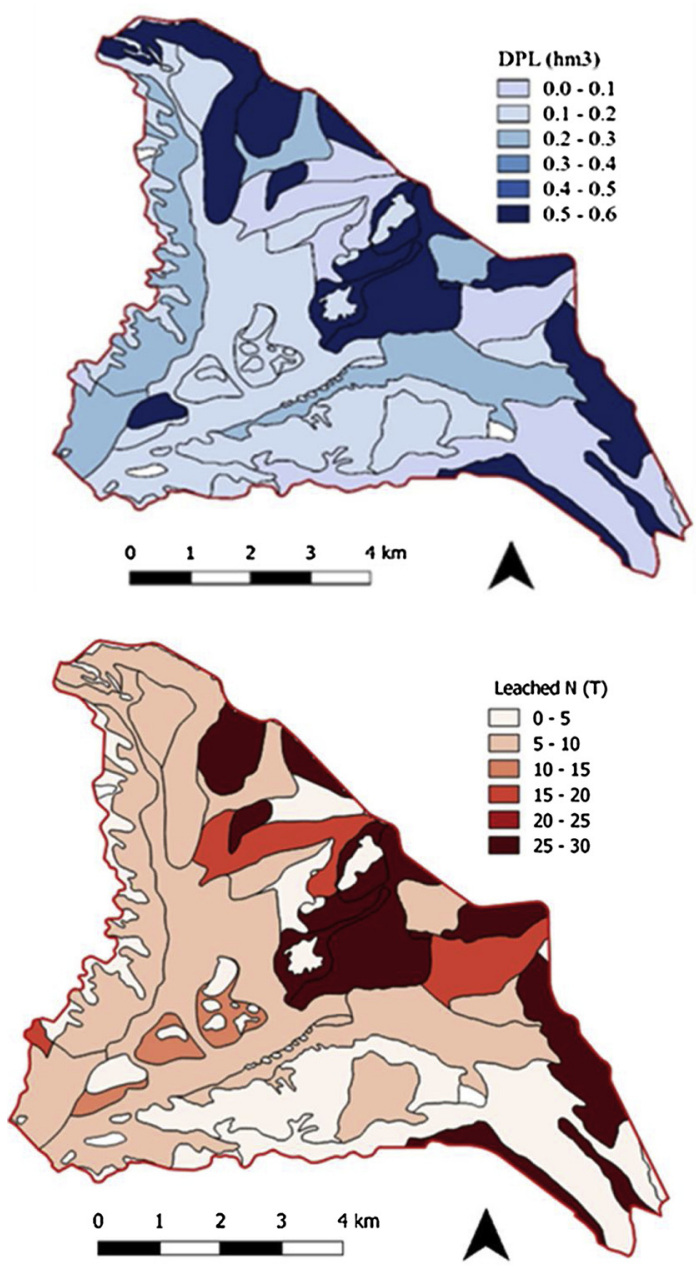

B) Optimal irrigation
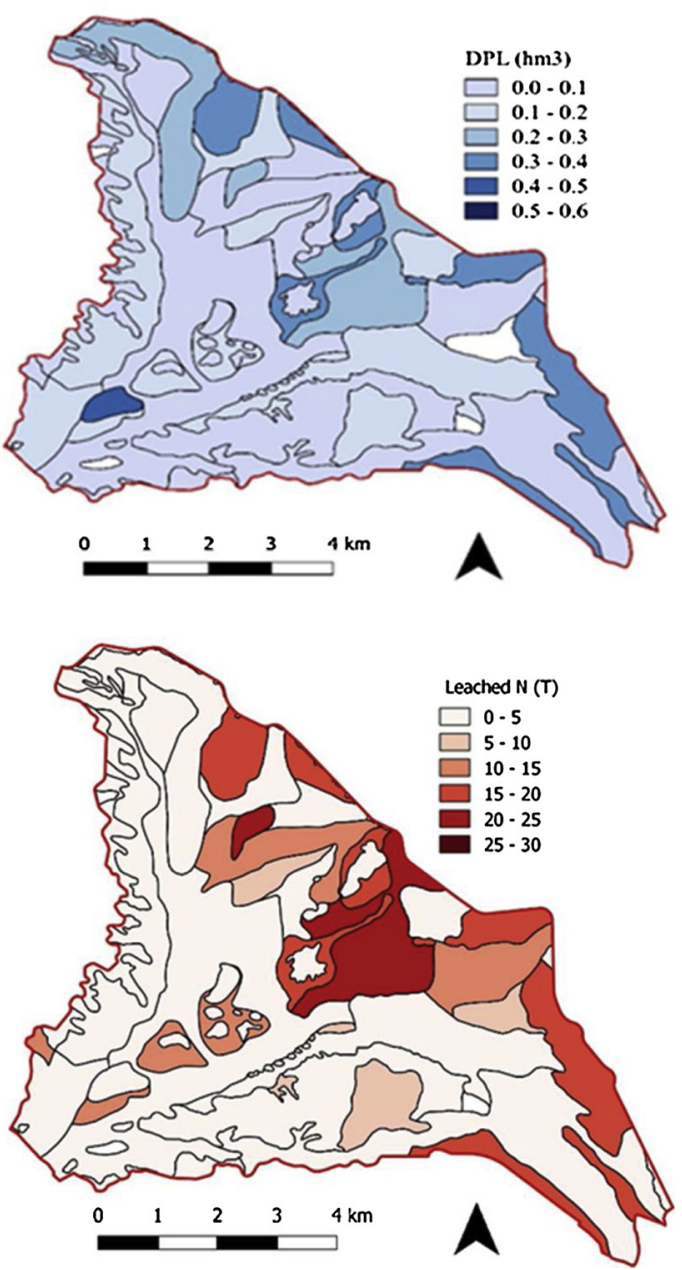

Fig. 8. Spatial distribution of average total deep percolation losses $\left(\mathrm{hm}^{3}\right)$ and leached $\mathrm{N}(\mathrm{T})$ under current irrigation (A) and optimal irrigation (B) in the VID.

this study showed that water use efficiency (WUE) was always higher under the optimal irrigation schedule for all the studied crops except wheat. For instance, after averaging the different soil types and years, the optimal irrigation schedule can improve the WUE by $22.5 \%, 22.0 \%$, $86.0 \%, 35.0 \%$ and $26.0 \%$ for maize-SS, maize-LS, sunflower, barley and alfalfa, respectively.

When calculating the two-cropping seasonal average of the total amount of irrigation lost by deep percolation in each soil type (considering the total area cultivated by each crop in each soil and the results presented in the previous section), approximately $1.16 \mathrm{hm}^{3}$ (34\%) of total deep percolation losses could be saved under the optimum irrigation schedule. The spatial distribution of water lost by deep percolation under the current and optimal irrigation schedules is presented in Fig. 8A and B, respectively. The results indicate that the highest water losses occurred in the A6, A4, B6 and C3 soils with the current irrigation schedule. However, those soils presented a different distribution pattern of reduction under optimal irrigation. The lowest reductions were found in the D2 and D3 soil types. In the other areas, 93.5\% of superficies (A1, A3, A4, A6, B6, C1, C2, C3, D4, D5, and E2) presented the same reduction pattern in the VID. Regardless of the soil type, the optimal irrigation schedule can reduce deep percolation by $63 \%, 86 \%, 23 \%$ and $46 \%$ for alfalfa, maize-SS, maize-LS and sunflower, respectively. Nonetheless, for barley and wheat, the deep percolation losses were $31 \%$ and $29 \%$ greater, respectively, under the optimal irrigation schedule due to the water stress demonstrated by the current irrigation during the crop season.

In the same way, the total $\mathrm{N}$ losses can be reduced under the optimal irrigation schedule by $8.09 \mathrm{~T}$ and $8.53 \mathrm{~T}$ for 2015 and 2016, respectively. In Fig. 8, it is observed that there was a reduction of leached $\mathrm{N}$ under the optimal irrigation management in the majority of the VID. Furthermore, $\mathrm{N}$ fertilization management must be assessed to potentially reduce $\mathrm{N}$ leaching. Regardless of the soil type, the optimal irrigation schedule can reduce leached $\mathrm{N}$ by $100 \%, 34 \%, 77 \%$ and $50 \%$ for alfalfa, maize-SS, maize-LS and sunflower, respectively. Nonetheless, for barley and wheat, the leached $N$ losses were $43 \%$ and $47 \%$ greater, respectively, under the optimal irrigation schedule due to the higher deep percolation losses demonstrated by the current irrigation during the crop seasons.

\section{Conclusion}

The current evaluation of irrigation performance in an intensive cropping system such as the VID showed that farmers' irrigation practices lack the management skills necessary to properly manage their irrigation systems. Regarding observed data, this study indicate that farmers' practices don't not match well with irrigation schedule and depth. Consequently, yields losses due to drought stress were identified, especially for wheat, barley and alfalfa, due to drought stress occurring during the crop season. In contrast, an excessive irrigation water depth was applied for maize-LS, maize-SS and sunflower. Regarding the DSSAT calibration and evaluation, the model demonstrated good performance for simulating maize, wheat, barley and sunflower crops in intensive cropping systems under Mediterranean conditions.

The DSSAT simulation of different water management scenarios 
indicated that the optimal irrigation management significantly improved the irrigation water use by adjusting the irrigation water applied according the actual evapotranspiration needs and the soil holding capacity instead of the farmers' current irrigation calendar.

A different behavior was observed for the A4, D4 and B6 soils, which demonstrated higher deep percolation losses and consequently leached $\mathrm{N}$ among the different crops and seasons than that in the E2, C2, C3 D5 and C1 soils. This behavior was identified for all the main crops in the VID (maize-LS, maize-SS, wheat, barley, sunflower and alfalfa). In fact, optimal irrigation was reduced using the DSSAT automatic irrigation (on average for different soil types and study years), and the total amount of seasonal drainage water was reduced by $70 \%$, $25 \%, 33 \%$ and $58 \%$ and the nitrate leaching by $33 \%, 77 \%$, and $52 \%$ without reductions in grain yield for maize-SS, maize-LS and sunflower, respectively. In the case of barley and wheat, there was no deep percolation loss, which was considered an improvement for the amount of $\mathrm{N}$ leached because these crops suffered from water stress. Finally, the leached $\mathrm{N}$ was negligible for the alfalfa crop, while an improvement of $50 \%$ was negligible for deep percolation losses under the optimal irrigation practices. With appropriate irrigation scheduling, deep percolation and transport of fertilizers out of the root zone are controlled, water logging is avoided, less water is used (i.e., water and energy saving), optimum soil water conditions are created for plant growth, and higher yields and better quality are obtained. Nonetheless, adjusting only irrigation schedules is not enough to reduce $\mathrm{N}$ leaching, especially when most $\mathrm{N}$ is retained in the soil, which represents a risk of $\mathrm{N}$ loss, especially if the land is left fallow over winter. The high level of residual $\mathrm{N}$ in the soil, especially for maize-LS (higher than $113 \mathrm{~kg} \mathrm{~N}$ $\mathrm{ha}^{-1}$ ), is prone to potential $\mathrm{N}$ leaching during the intercrop period (October-April) and at the start of the following crop growing season, when the crop $\mathrm{N}$ uptake is low and maize roots are not deep in the soil profile. Nonetheless, irrigation management alone cannot effectively reduce $\mathrm{N}$ leaching in intensive irrigated areas because $\mathrm{N}$ fertilizer and irrigation management are important for reducing nutrient losses and increasing resource efficiency. Although the presented results support the potential of the DSSAT model to incentivize farmers to enhance their irrigation practices, the soil proprieties must still be considered to ensure production while improving environmental sustainability.

\section{Acknowledgements}

This work was funded by the Ministry of Economy and Competitiveness of the Spanish Government through the research grants (AGL2013-48728-C2-2-R). We thank this Ministry for awarding Wafa Malik a predoctoral fellowship. Thanks are given also to the Almudévar Water User Association and to CSIC/CITA field staff and technicians for their technical support.

\section{References}

Abd El Baki, H.M., Fujimaki, H., Tokumoto, I., Saito, T., 2018. A new scheme to optimize irrigation depth using a numerical model of crop response to irrigation and quantitative weather forecasts. Comput. Electron. Agric. 150, 387-393.

Allen, R.G., Pereira, L.S., Raes, D., Smith, M., 1998. Crop Evapotranspiration-Guidelines for Computing Crop Water Requirements-FAO Irrigation and Drainage Paper 56, vol. 300 FAO, Rome p. D05109.

Andarzian, B., Hoogenboom, G., Bannayan, M., Shirali, M., Andarzian, B., 2014. Determining optimum sowing date of Wheat using CSM-CERES-Wheat model. J. Saudi Soc. Agric. Sci. 14, 189-199.

Arora, V.K., Singh, H., Singh, B., 2007. Analyzing Wheat productivity responses to climatic, irrigation and fertilizer-nitrogen regimes in a semi-arid sub-tropical environment using the CERES-Wheat model. Agric. Water Manage. 94, 22-30.

Ashfaq, A., Ali, A., Khaliq, T., Wajid, S.A., Iqbal, Z., Ibrahim, M., Javeed, H.M.R., Hoogenboom, G., 2013. OILCROP-SUN model relevance for evaluation of nitrogen management of sunflower hybrids in Sargodha, Punjab. Am J. Plant Sci. 4, $1731-1735$

Awais, M., Wajid, A., Nasim, W., Ahmad, A., Saleem, M.F., Sammar Raza, M.A., Bashir, M.U., Habib-ur-Rahman, M., Saeed, U., Hussain, J., Arshad, N., Hoogenboom, G., 2017. Modeling the water and nitrogen productivity of sunflower using OILCROPSUN model in Pakistan. Field Crops Res. 205, 67-77.
Aznar, J.M., Claret, R.M.P., Badía, D., 2013. Soil catena along gypseous woodland in the middle Ebro Basin: soil properties and micromorphology relationships. Span. J. Soil Sci. 3, 28-44.

Burt, C.M., Clemmens, A.J., Strelkoff, T.S., Solomon, K.H., Bliesner, R.D., Hardy, L.A., Howell, T.A., Eisenhauer, D.E., 1997. Irrigation performance measures: efficiency and uniformity. J. Irrig. Drain. Eng. 123, 423-442.

Callison, D., 2012. Management Allowed Depletion Irrigation Scheduling. Available online at: http://awqa.org/wp-content/toolkits/IrrigationScheduling/ ManagementAllowedDepletion-IrrigationScheduling.pdf (Accessed 8 June 2018).

Chen, Y., Marek, G.W., Marek, T.H., Brauer, D.K., Srinivasan, R., 2018. Improving SWAT auto-irrigation functions for simulating agricultural irrigation management using long-term lysimeter field data. Environ. Modell. Softw. 99, 25-38.

Clemmens, A.J., Burt, C.M., 1997. Accuracy of irrigation efficiency estimates. J. Irrig. Drain. Eng. 123, 443-453.

Clemmens, A.J., Dedrick, A.R., 1994. Irrigation techniques and evaluations. In: Tanji, K.K., Yaron, B. (Eds.), Advanced Series in Agricultural Sciences. Springer, Berlin, pp. 64-103.

Dar, E.A., Brar, A.S., Mishra, S.K., Singh, K.B., 2017. Simulating response of Wheat to timing and depth of irrigation water in drip irrigation system using CERES-Wheat model. Field Crops Res. 214, 149-163.

Dechmi, F., Playán, E., Faci, J.M., Tejero, M., 2003. Analysis of an irrigation district in northeastern Spain. I. Characterization and water use assessment. J. Agric. Water Manage. 61, 75-92.

FAO, 2016. Food and Agricultural Organization of the United Nation. AQUASTAT, Information System on Water and Agriculture (Accessed 05 August 2018). www.fao. $\mathrm{org} / \mathrm{nr} /$ water/aquastat/water use/index.stm.

Gheysari, M., Mirlatifi, S.M., Bannayan, M., Homaee, M., Hoogenboom, G., 2009. Interaction of water and nitrogen on maize grown for silage. Agric. Water Manage. 96, 809-821.

Gijsman, A.J., Hoogenboom, G., Parton, W.J., Kerridge, P.C., 2002. Modifying DSSAT crop models for low-input agricultural systems using a soil organic matter-residue module from CENTURY. Agron. J. 94, 462-474.

Hammad, H.M., Abbas, F., Ahmad, A., Farhad, W., Anothai, J., Hoogenboom, G., 2017. Predicting water and nitrogen requirements for Maize under semi-arid conditions using the CSM-CERES-Maize model. Eur. J. Agron. https://doi.org/10.1016/j.eja. 2017.10.008.

Heng, L.K., Asseng, S., Mejahed, K., Rusan, M., 2000. Optimizing wheat productivity in two rainfed environments of the west Asia-North Africa region using a simulation model. Eur. J. Agron. 26, 121-129.

Hoogenboom, G., Jones, J.W., Wilkens, P.W., Porter, C.H., Batchelor, W.D., Hunt, L.A., Boote, K.J., Singh, U., Uryasev, O., Bowen, W.T., Gijsman, A.J., du Toit, A., White, J.W., Tsuji, G.Y., 2004. Decision Support System for Agrotechnology Transfer, Version 4.0. University of Hawaii, Honolulu, HI.

Hoogenboom, G., Porter, C.H., Shelia, V., Boote, K.J., Singh, U., White, J.W., Hunt, L.A Ogoshi, R., Lizaso, J.I., Koo, J., Asseng, S., Singels, A., Moreno, L.P., Jones, J.W., 2017. Decision Support System for Agrotechnology Transfer (DSSAT) Version 4.7. DSSAT Foundation, Gainesville, Florida, USA. https://DSSAT.net.

Hundal, S., Prabhjyot-Kaur, 1997. Application of the CERES-Wheat model to yield predictions in the irrigated plains of the Indian Punjab. J. Agric. Sci. 129, 13-18.

Isidoro, D., Quílez, D., Aragüés, R., 2004. Water balance and irrigation performance analysis: La Violada irrigation district (Spain) as a case study. J. Agric. Water Manage. 64, 123-142.

Isidoro, D., Quilez, D., Aragues, R., 2006. Environmental impact of irrigation in la Violada district (Spain): I. Salt export patterns. J. Environ. Qual. 35, 766-775.

Jahan, M.A.H.S., Sen, R., Ishtiaque, S., Choudhury, A.K., Akhter, S., Ahmed, F., Biswas, J.C., Manirruzaman, M., Miah, M.M., Rahman, M.M., Kalra, N., 2018. Optimizing sowing window for wheat cultivation in Bangladesh using CERES-wheat crop simulation model. Agric. Ecosyst. Environ. 258, 23-29.

Jiménez-Aguirre, M.T., Isidoro, D., 2018. Hydrosaline balance in and nitrogen loads from an irrigation district before and after modernization. Agric. Water Manage. 208, $163-175$.

Jiménez-Aguirre, M.T., Isidoro, D., Usón, A., 2018. Soil variability in La Violada Irrigation District (Spain): I delineating soil units for irrigation. Geoderma 311, 78-90.

Jones, J.W., Hoogenboom, G., Porter, C.H., Boote, K.J., Batchelor, W.D., Hunt, L.A. Wilkense, P.W., Singhe, U., Gijsmana, A.J., Ritchie, J.T., 2003. The DSSAT cropping system model. Eur. J. Agron. 18, 235-265.

Kadiyala, M.D.M., Jones, J.W., Mylavarapu, R.S., Li, Y.C., Reddy, M.D., 2015. Identifying irrigation and nitrogen best management practices for aerobic rice-maize cropping system for semi-arid tropics using CERES-rice and maize models. Agric. Water Manage. 149, 23-32.

Lamm, F.R., Rogers, D.H., Clark, G.A., 1996. Irrigation scheduling for corn: macro management. Proc. Evapotranspiration and Irrigation Scheduling Conf. ASABE 741-748.

Lecina, S., Isidoro, D., Playán, E., Aragüés, R., 2010. Irrigation modernization in Spain: effects on water quantity and quality-a conceptual approach. Int. J. Water Resour. Dev. 26, 265-282.

Li, Z.T., Yang, J.Y., Drury, C.F., Hoogenboom, G., 2015. Evaluation of the DSSAT-CSM for simulating yield and soil organic $\mathrm{C}$ and $\mathrm{N}$ of a long-term maize and wheat rotation experiment in the Loess Plateau of Northwestern China. Agric. Syst. 135, 90-104.

Liu, H.L., Yang, J.Y., Drury, C.F., Reynolds, W.D., Tan, C.S., Bai, Y.L., He, P., Jin, J., Hoogenboom, G., 2011. Using the DSSAT-CERES-Maize model to simulate crop yield and nitrogen cycling in fields under long-term continuous Maize production. Nutr. Cycl. Agroecosyst. 89, 313-328.

Liu, H.L., Yang, J.Y., He, P., Bai, Y., Jin, J., Drury, C.F., Zhu, Y., Yang, X., Li, W., Xie, J., Yang, J., Hoogenboom, G., 2012. Optimizing parameters of CSM-CERES-maize model to improve simulation performance of maize growth and nitrogen uptake in northeast 
China. J. Integer. Agric. 11, 1898-1913.

López-Cedrón, F.X., Boote, K.J., Piñeiro, J., Sau, F., 2008, Improving the CERES-maize model ability to simulate water deficit impact on maize production and yield components. Agron. J. 100, 296-307.

MAAA- Ministerio de Agricultura, 2015. Alimentación y Medio Ambiente. Informe anual de indicadores.

Malik, W., Boote, K.J., Hoogenboom, G., Cavero, J., Dechmi, F., 2018. Adapting the CROPGRO model to simulate alfalfa growth and yield. Agron. J. 110. https://doi.org/ 10.2134/agronj2017.12.0680.

Maynard, D.N., Olson, S.M., 2001. Vegetable Production Guide for Florida 2001-2002. Extension, Institute of Food and Agricultural Science, the University of Florida.

McCown, R.L., Carberry, P.S., Dalgliesh, N.P., Foale, M.A., Hochman, Z., 2012. Farmers use intuition to reinvent analytic decision support for managing seasonal climatic variability. J. Agric. Syst. 106, 33-45.

Ongley, E.D., 1996. Control of Water Pollution from Agriculture. FAO Irrig. and Drain. Paper $\mathrm{n}^{\circ}$ 55, Rome, Italy $112 \mathrm{pp}$.

Rasse, D.P., Ritchie, J.T., Wilhelm, W., Wei, J., Martin, E.C., 2000. Simulating inbredmaize yields with CERES-IM. Agron. J. 92, 672-678.

Rinaldia, M., Losavioa, N., Flagellab, Z., 2003. Evaluation and application of the OILCROP SUN model for sunflower in southern Italy. Agric. Syst. 78, 17-30.

Ritchie, S., Hanway, J.J., 1982. How a Corn Plant Develops. Iowa State Univ. of Science and Technology. Coop. Ext. Service 48 p.

Rötter, R.P., Palosuo, T., Kersebaum, K.C., Angulo, C., Bindi, M., Ewert, F., Ferrise, R., Hlavinka, P., Moriondo, M., Nendel, C., Olesen, J.E., Patil, R.H., Ruget, F., Takáč, J., Trnka, M., 2012. Simulation of spring barley yield in different climatic zones of Northern and Central Europe: a comparison of nine crop models. Field Crops Res. 133, 23-36.

Salmerón, M., Cavero, J., Isla, R., Porter, C.H., Jones, J.W., Boote, K.J., 2014. DSSAT nitrogen cycle simulation of cover Crop-Maize rotations under irrigated Mediterranean conditions. Agron. J. 106, 1283-1296.
Schneiter, A.A., Miller, J.F., 1981. Description of sunflower growth stages. Crop Sci. 21, 901-903.

Seidel, S.J., Palosuo, T., Thorburn, P., Wallach, D., 2018. Towards improved calibration of crop models - where are we now and where should we go? Eur. J. Agron. 94, 25-35.

Skhiri, A., Dechmi, F., 2012. Impact of sprinkler irrigation management on the Del Reguero river (Spain). I: water balance and irrigation performance. Agric. Water Manage. 103, 120-129.

Staggenborg, S.A., Vanderlip, R.L., 2004. Crop simulation models can be used as dryland cropping systems research tools. Agron. J. 97, 378-384.

Tanji, K.K., Kielen, N.C., 2002. Agricultural Drainage Water Management in Arid and Semiarid Areas. FAO Irrig. Drain. Paper nº 61, Rome, Italy 188 pp.

Timsina, J., Humphreys, E., 2006. Performance of CERES-rice and CERES-Wheat models in rice-Wheat systems: a review. Agric. Syst. 90, 5-31.

Travasso, M.I., Magrin, G.O., 1998. Utility of CERES-barley under argentine conditions. Field Crops Res. 57, 329-333.

Walker, W.R., Skogerboe, G.V., 1987. Surface Irrigation. Theory and Practice. PrenticeHall, Englewood Cliffs, NJ, USA 386 pp.

Wei, Y., Chen, D., Hu, K., Willett, I.R., Langford, J., 2009. Policy incentives for reducing nitrate leaching from intensive agriculture in desert oases of Alxa, Inner Mongolia. China. Agric. Water Manage. 96, 1114-1119.

Willmott, C.J., 1982. Bulletin American, vol. 63. Meteorological Society, pp. 1309-1313.

Xie, Y., Kiniry, J.R., Nedbalek, V., Rosenthal, W.D., 2001. Maize and sorghum simulations with CERES-maize, SORKAM, and ALMANAC under water-limiting conditions. Agron. J. 93, 1148-1155.

Yakoub, A., Lloveras, J., Biau, A., Lindquist, J.L., Lizaso, J.I., 2017. Testing and improving the maize models in DSSAT: development, growth, yield, and $\mathrm{N}$ uptake. Field Crops Res. 212, 95-106.

Zadoks, J.C., Chang, T.T., Konzak, C.F., 1974. A decimal code for growth stages of cereals. Weed Res. 14, 415-421. 